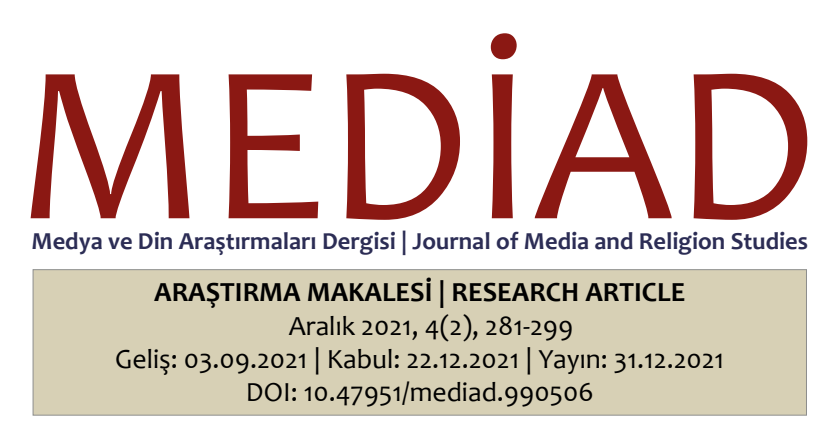

\title{
Sosyal Medyada İslamofobik Paylașımlar: Twitter Örneği
}

\author{
Mehmet Sinan TAM*
}

\section{Öz}

Günümüzde milyarlarca kişi tarafından takip edilen sosyal medya uygulamalarıyla İslamofobinin kendisi canlı kalmakla birlikte, söz konusu durum yeni bir boyut kazanarak sanal âleme taşınmıştır. Müslüman dünyası dışında kendini konumlandıran bir kavram olmakla birlikte, günümüzde artık İslam coğrafyalarında da İslamofobik durumlarla karşılaşılmaktadır. Sosyal medyada íslamofobik paylaşımları konu edinen bu araştırmada; 25.10.2020 - 03.01.2021 tarihleri arasında Twitter'da Allah (c.c.) kullanıcı adıyla paylaşımda bulunan hesabın tweetleri (250) ve bu hesabı takip edenlerin bu tweetlere yaptığı paylaşımlar (9440) Maxqda programıyla alınmıștır. Nitel anlamda incelenen verilerle ilgili hesap ve takip edicilerin Allah, peygamberler, melek, Kur'an-ı Kerim, Müslümanlar, ahiret inancı ve farzlar (namaz, oruç) başta olmak üzere dini değer ve söylemleri alaya alan İslamofobik paylaşımlar yaptığı tespit edilmiştir. Araştırmada ele alınan örnek özelinde geleneksel medyada periyodik aralıklarla gündeme gelen İslamofobik söz ve eylemlerin her an sosyal medyada üretildiği sonucuna ulaşıımıştır. Çalışma; İslam özelinde yapılan bu tür tahkirlere ilişkin Türkiye'nin uluslararası kuruluşlarla yapılacak manevi değerlerin korunmasın öncü rol oynamasını gündeme getirmektedir.

Anahtar Kelimeler: İslamofobi, Anti-İslamizm, Türkiye, Twitter

\section{Islamophobic Posts on Social Media: The Twitter Case}

\begin{abstract}
Although Islamophobia itself remains alive with social media applications followed by billions of people today, the situation in question has taken on a new dimension and moved into the virtual world. Although it is a concept that positions itself outside the Muslim world, nowadays Islamophobic cases are also encountered in Islamic geographies. In this research, which deals with Islamophobic posts between 25.10.2020 and 03.01.2021 on social media, the tweets (250) of the account which were shared on Twitter with the username Allah and the shares (9440) of those who follow this account to these tweets were taken with the Maxqda program. The data analyzed qualitatively mock religious values and discourses. It has been determined that the account made Islamophobic posts, in particular on Allah, prophets, angels, Qur'an, Muslims, belief in the hereafter, and obligatory prayers (prayer, fasting). It has been concluded that Islamophobic words and actions that come to the agenda in traditional media periodically are produced in social media at any time. The study brings forward that Turkey should play a leading role in the protection of moral values to be made with international organizations regarding such insults made specifically against Islam.
\end{abstract}

Keywords: Islamophobia, Anti-Islamism, Islam, Turkey, Twitter

ATIF: Tam, M. S. (2021). Sosyal medyada İslamofobik paylaşımlar: Twitter örneği. Medya ve Din Araştırmaları Dergisi (MEDIAD), 4(2), s. 281-299. 


\section{Giriş}

İslamofobinin tam olarak ne zaman kitlesel bir hale dönüştüğünü kestirmek mümkün değildir. Bu durumun kavramsallaştığı tarihin 20. yy’a rast geldiği ve burada dönüm noktası olan tarihinse 11 Eylül 2001 olduğu söylenebilir. Bu tarihten sonra Müslümanlara karşı duyulan nefret, korku ve İslam karşıtlı̆̆ı söylemler önceki yıllara nisbeten daha fazla artmıştır (Sheridan, 2006, s. 317). 2000'li yılların başlarında yaşanan terör eylemleri, i̇slamofobik fikirlerin hızla yayılmasına adeta zemin hazırlamıştır (Massoumi, Mills ve Miller, 2017). İslamofobik düşüncelerin kitlelerce benimsenmesinde; anti-islamik duygu ve tutumlar, Müslümanlara karşı benimsenen ön yargılar, komplo teorileri, İslam dininden ve Müslümanlardan korkma, nefret etme ve iğrenme de etkili olmuştur (UenaL, Bergh, Sidanius vd., 2021, s. 280). Bu olumsuz fikirleri benimseyenler, kendi ideolojik veya dini öğretilerine ters düşse dâhi İslamofobik düşünceleri rahatlıkla içselleştirebilmektedir (López, 2011, s. 569).

Teknoloji, bilgi ağları, kültür ve iletişimin küresel bir boyut kazanması; toplum ve yasalar arasında ciddi değişim/dönüşümlere neden olmuştur (Perry ve Olsson, 2009, s. 196). Bu durum yeni küresel sorunları da beraberinde getirmiştir. Siber suçlar altında sınıflandırılan nefret, kin, ayrımclık, küçük düşürme, alaya alma vb. durumlar bu değişim/dönüşümün sonucunda ortaya çıkan problemler olmuştur. Siber suçlar genellikle sosyal medyanın araç olarak kullanılmasıyla küresel bir boyuta dönüşmektedir (Burnap ve Williams, 2015). Birtakım gruplar tarafından kasti olarak yürütülen kampanyalarla; inanç sistemlerine, kültürel değerlere, kimlik ve göçmenlere yönelik daha çok siber saldırılar yapılmaktadır (Douglas, McGarty, Bliuc ve Lal, 2005; Chau ve $\mathrm{Xu}, 2007)$.

Her ne kadar ilk bakışta İslamofobik tutumlar, İslam inancının az sayıda kişilerce benimsendiği coğrafyalarda daha fazla yaşandığı düşünülse de bu tarz ideolojik saplantılar, nüfusunun büyük bir kesimi Müslüman olan ülkelerde bile yaşanabilmektedir. Türkiye'de son yıllarda İslamofobiye; hukuk, üniversite, iş yeri, reklam ve televizyon görüntüleri, film ve pembe dizilerin araç yapıldığı mecralarda karşılaşılmaktadır (Yel ve Nas, 2014). Bu i̇slamofobik eğilimlerin geniş tabanlara yayılmasında ise medya kanalının benimsediği ideoloji ve politikadaki şahsiyetler önemli bir role sahip olmuștur (Temel, 2020, s. 164; Terri, 2019). Öte yandan özellikle sosyal medya uygulamalarıyla ana akım ve politika düzleminde gerçekleşen İslamofobik durumlar, farklı formatlara dönüștürülerek sosyal medya platformlarıyla yeniden üretilmektedir. Dolayısıyla sosyal medya platformları da İslamofobik fikirlerin kitlesel bir hale dönüşmesinde belirleyici olmaktadır.

Literatürde Twitter özelinde yapılan İslamofobik çalışmalar, Müslüman dünyasından ziyade daha çok Müslüman nüfusun azınlıkta kaldığı ülkeleri konu edinmiştir. Türkçe paylaşımlarla İslamofobiyi meşrulaştıran Twitter hesaplarına iliş̧in ise herhangi bir çalışmaya rastlanılmamıştır. Bu bağlamda ele alınan çaıışma; Twitter'da Müslümanların maddi ve manevi değerlerine ilişkin Türkçe paylaşılan İslamofobik tweetleri ortaya çıkartmayı amaçlamıştır. Türkçe içeriklerle İslamofobik paylaşımlar yapan onlarca Twitter hesabı bulunmaktadır. Araştırmada en çok takipçi sayısına sahip (222,2 Bin) Allah (c.c.) adlı @CenabiAllah kullanıcı isimli Twitter hesabı ve bu hesabı takip edenlerin 25.10.2020 - 03.01.2021 tarihleri arasındaki erişime açık yazılı tweetleri incelenmiştir. Söz konusu tweetler, nitel araştırmalar içerisinde sıklıkla kullanılan içerik analizi yöntemiyle ele alınmış ve Maxqda programıyla analizleri gerçekleştirilmiştir.

Çalışmada; sosyal medya ve İslamofobi ilișkisinde nelerin ön planda olduğu, takip edicilerin İslamofobik paylaşımlara hangi tepkileri verdiği ve hangi İslamofobik görünümlerin sıklıkla Twitter'da paylaşıldığı sorularına cevap aranmıştır. Bu sorular ışığında araştırma; self oryantalist bakış açısından hareketle, Twitter'da gerçekleşen İslamofobik görünümleri keşfetmeyi hedeflemektedir. Araştırma neticesinde; gündelik yaşantıda periyodik aralıkla geleneksel medyada gündeme gelen İslamofobik söz ve eylemlerin her an sosyal medya hesaplarında üretildiği sonucuna ulaşılmıştır. Çalışma, üç dinin ortak argümanı ve evrensel bir değer olan yaratıcıya yönelik yapılan bu tür tahkirlere ilişkin uluslararası kuruluşlarla yapılacak manevi değerlerin korunmasında, başta Türkiye olmak üzere, İslam coğrafyasının sonuç odaklı roller oynamasını gündeme getirmektedir.

\section{İslamofobi / Anti-islamizm}

En genel anlamıla İslamofobi; i̇slam dini ve bu dinin mensuplarına karşı takınılan negatif tutum veya duyguları ifade etmektedir (Bleich, 2012, s. 185). Kökeni Fransızca 'Islamophobie' kelimesinden gelen İslamofobi kavramı, ilk kez 1920'lerde kullanılmıştır. 1970'lere gelindiğinde ise İran Devrimiyle birlikte İslamofobi, i̇slam dinine inanan kişilerin geleneklerini reddetme veya yok sayma şeklinde kendini göstermiştir. Bu dönemde özellikle Müslüman kıyafetlerini korkutucu görenler İslamofobik tutumları daha fazla benimsemiştir. İran Devrimi dışında ırk veya ten rengine yönelik gerçekleştirilen fiilerle de İslamofobi, milenyum öncesi dönemde kendini farklı şekillerde görünür kılmıştır. 1997'de Runnymede Trust tarafından yayımlanan 'islamofobi: Hepimiz için Bir Zorluk' raporuyla, kavram günümüzdeki kullanımına yakın bir anlamda ifade edilmiş̧tir. Daha sonraki yıllarda ise dünya üzerinde gelişen özellikle de siyasi cereyanlarla birlikte, kavramın içeriği farklı yönlere evrilmiştir (Allen, 2007; Allen, 2010c). ilgili rapordan hareket eden Kumar (2007) ile Abbas (2011) İslamofobik 
fikirlerin temelinde şu düşüncelerin yattığını belirtmişlerdir: Müslüman kültürler monolitiktir, İslam cinsiyetçi bir dindir, Müslüman zihni rasyonellik ve bilim yeteneklerine sahip değildir, şiddet İslam'ın doğasında vardır, batı demokrasiyi, İslam ise terörizmi yayar, İslam kültürü diğer kültürlerden önemli ölçüde farklıdır, İslam amansız bir tehdit unsurudur, İslam taraftarları siyasi ve askeri avantaj elde etmek için inançlarını kullanırlar, batılı toplumların İslam hakkındaki eleştirileri batılılar tarafından tamamen reddedilir, İslam korkusu ırkçılıkla karıștırılır ve İslamofobik eylemler doğal ve sorunsuz olarak kabul edilir.

Sosyal medyada İslam ve Yahudi inancına yönelik takınılan aykırı ve ayrılıkçı fikirler; siber suçlar veya nefret söylemi başlığı altında birleşmektedir. Yahudi inancına sahip olanlar Antisemitizmle özellikle kıta Avrupası'nda tarih boyunca karşılaşmıştır. Bilinen en son ve en büyük Antisemitizm ise II. Dünya savaşı döneminde yaşanmıştır. İslamofobi ve Antisemitzm nefret söylemi bağlamında ortak bir zeminde buluşmaktadır Fakat Antisemitizmde ırk/soy/köken hedeflenirken, İslamofobi de ise dini değerler ve Müslümanlar nefret söylemine konu olmaktadır (Meer, 2013). Son yıllarda Avrupa ülkelerinde İslamofobik eylemler, aynı zamanda İslam'ın yaşandığı coğrafyalardaki ulus kimliklere (Turkophobia vb.) yönelik yapılan ayrımcılık, şiddet, korku ve nefret davranışlarıyla birlikte yapılmaktadır (Bayraklı ve Hafez, 2020). İslamofobi kavramı, her ne kadar bir ırk veya ulusa ait insanlık dışı takınılan tutum ve değerleri içinde barındırsa da söz konusu kavramın çıkış ideasından farklılaşarak, insanlığın manevi değerlerini tahkir etmeye yönelik şekillendiği ifade edilebilir. Öte yandan İslamofobi, Antisemitizmden farklı olarak hala tüm dünyada resmî anlamda kabul görülen bir ayrımcılık/ötekileştirme olarak görülmemektedir. Bu durum İslamofobik eylemlerin göz ardı edilmesine ve yapılanın olağan görülüp yayılmasına da meşru bir zemin hazırlamaktadır.

Üç dinin ortak argümanlarından biri olan Allah (c.c.) kavramı, 11 Eylül'den sonra kavramın taşıdığı anlama ilişkin tartışmaları da beraberinde getirmiştir. 11 Eylül saldırılarından sonra Evanjelist Hristiyanlar, Müslümanlarla ortak olan bu kavramın kendi Tanrı inançlarıyla farklılık taşıdığını ifade ederek, bu noktada Allah lafzına yönelik İslamofobik söylemlerin artmasına zemin hazırlamıştır (Cimino, 2005, s. 165; Jung, 2012). Evanjelistler, Kuran-ı Kerim'de geçen ayetler üzerinden hareket ederek Allah'ın; şiddeti teşvik ettiği, Müslüman olmayanların öldürülmesini ve terörü hedeflere ulaşmada bir araç olarak Müslümanlara sunduğuna dair bâtıl düşünceleri kitlelerin zihinlerinde oluşturmaya çalışmıştır (Gökmen, 2018, s. 93). Nitekim bu tarz mesnetsiz söylemler, sonraki yıllarda Allah lafzı kullanılarak fakat bu kez karikatürize bir biçimde kitlelere sunularak kara propagandaya uğramıştır (Büyüktopçu ve Gündoğdu, 2019).

Edward Said (1978) tarafından ortaya konulan oryantalizm düşüncesinde batının, doğu medeniyetleri başta olmak üzere, diğer medeniyetlere karşı kendini üstün görme bakış açısını konu edinmektedir. Burada batılı medeniyetler tarafından değil de doğulu medeniyetlerin kendileri hakkındaki oryantalist bakış açısına ise self-oryantalizm kavramı kullanılarak ifade edilmiştir (Dirlik, 1996). Dolayısıyla self oryantalist düşünce sisteminde; doğu medeniyetlerinin bizatihi kendileri, öz değerlerine ilişkin çeşitli ön kabulleri ve ön yargıları benimsemesini içermektedir. Bu fikirlerin benimsenmesinde edebiyat, toplumlararası ilişkiler ve medyanın önemli oranda etkisi bulunmaktadır (Özçelik, 2021). Müslüman toplumlar içinde self-oryantalist fikirler, aynı zamanda İslam inancı üzerine de yapılmaktadır. Bu noktada gerçekleşen İslamofobik durumlar ülkeden ülkeye farklılık göstermektedir (Bayraklı \& Yerlikaya, 2017). Türkiye, Pakistan, Mısır, Arnavutluk ve Malezya özelinde yapılan araştırmalarda bu durum akademik anlamda ortaya konulmuştur. Ülke bazında değerlendirildiğinde, Türkiye'de gerçekleştirilen İslamofobik olaylarda; başörtüsü, sakal ve yöresel kıyafetler cumhuriyet projesi önünde bir engel olarak görülmüştür. Burada sıralanan dış görünümlerden hareket eden bazı kesimler, belli dönemlerde İslamofobik düşüncelerini söz veya eylemlerle gerçekleştirmiştir. Bu yaklaşımı benimseyenlerin sığındığı slogan cümle ise 'íslam'ın çağdaş medeniyetler seviyesine ulaşmada bir engel olacağı' yanılgısıdır. Öte yandan İslamiyet'in Arap yarımadasından çıkması nedeniyle, bu tarz giyinişler, İslamofobik bakışların yanı sıra zaman zaman ırkçı yaklaşımları da beraberinde getirmiştir (Yel, 2021).

Türkiye'de İslamofobik söylemler seküler milliyetçiler tarafından laiklik başlığı altında yapılırken, kıta Avrupa'sında yer alan Arnavutluk'ta; Avrupa'nın diğer devletleriyle Arnavutluk'un müttefik/dost olmasında engel teşkil eden durum, ülkedeki Müslüman nüfusun çoğunlukta olması görülmektedir. Ülke içinde gerçekleşen İslamofobik söylemler bu yönde kamuoyu oluşturmaktadır (Aslan, 2019, s. 88; Beka, 2019, s. 55). Pakistan'da liberal seküler elitler, Malezya'da yoğun olarak ırkçılık ve medya eliyle, Mısır'da ise siyasi arena ve televizyon şovlarıyla İslamofobik söylemler vücut bulmaktadır (Shah, 2019, s. 69; Osman, 2019, s. 171; Zahed, 2019, s. 156). Tüm bu İslamofobik söylemlere maruz kalan kesimin daha çok kadınlar olduğu, burada söylemler dışında (terörist, kafanı kopartacağım, vb.) fiili saldırı veya psikolojik baskılara uğramada da yine yoğun bir şekilde karşılaşan kadınlar olmuştur (Himmat, 2004).

\section{Sosyal Medyada İslamofobik Paylaşımlar}

Türkiye'de geleneksel medya araçlarında İslamofobik paylaşımların izlerini görmek mümkündür. Bu noktadaki yayım/yayınlar; Gırgır, Leman, Uykusuz ve Penguen dergilerinde, Cumhuriyet, Milliyet ve Hürriyet 
gazetelerinde ve Yeşilçam sinemasında örtük veya açık bir şekilde yapılmıștır. Örneğin, Penguen Dergisi tarafından 2011 yılında yayımlanan bir karikatürde; "Allah Yok Din Yalan” şeklindeki yazı, Arapça fonla imam-hâtip önünde çizilerek İslamofobik sınırları da aşan bir skandala imza atılmıştır (Akıner ve Mencet, 2016, s. 176; Bayraklı ve Yerlikaya, 2017, s. 58). Medyanın sergilediği bu tavır sadece günümüzle sınırlı değildir. Geçmiş dönemlerde de medya, İslam değerlerini karalamaya yönelik birtakım kirli ideolojilere bilerek hizmet etmiștir (Zaal, 2012, s. 556). Ülkemizde medya eliyle yapılan İslamofobik haberlerde sıklıkla dindar - dinsiz, laik - anti-laik ve çağdaş/modern - gerici/yobaz gibi nitelemeler üzerinden haber dili oluşturulmuştur (Kurtuluş, 2009, s. 152). Anti-islamist tavırlar sadece medyayla kısıtlı kalmayarak farklı dönemlerde birtakım kişi ve/veya kurumlarca da popüler hale getirilmeye çalışılmıştır (Kaya ve Akıncı, 2018, s. 88). Son yıllarda geleneksel medyadaki kişiler ve kurumlar dışında sosyal medya platformlarında da İslamofobik izler görülmektedir.

Sosyal medya uygulamalarında dijital nefret ve terörizm, geçmişe kıyasla \%25 oranında artmıştır. Bu siber suçların 10.000'den fazla forum, web portalı, sosyal medya hesabı, blog, video ve oyun tabanlı web sayfasında bulunduğu tespit edilmiștir (Jaishankar, 2008). İslamiyet'e inanan kesime ilișkin yapılan olumsuz eylemlerin İslamofobiyle ilgili olmadığı, bunun nefret söylemi içerisinde gerçekleşen bir siber suç olduğunu belirten bir düşünce de bulunmaktadır (Aguilera-Carnerero ve Azeez, 2016). Bu yönüyle konu, hukuki bakımdan bir suç potansiyeline de sahip olduğundan, ilgili yasa koyucular tarafından bir ulus veya bir toplumun benimsediği maddi ve manevi değer, kişi ve tarihi öğelere yapılan tahkirler başlığı altında, söz konusu durum hakkında cezai müeyyideler hazırlanabilir.

11 Eylül saldırısından sonra sahte haberler ve dezenformasyonlarla İslamofobi hiç olmadığı kadar hızlı bir şekilde medya aracılığıyla yayılmıştır. Sosyal medya araçlarıyla, sahte haberler, komplo teorileri ve dezenformasyonlarla sadece geleneksel medya ve seçkinleri değil, sosyal medyayı deneyimleyen neredeyse her kullanıcı da bu sürecin bir parçası haline gelmiştir. Sosyal medya sadece İslamofobiye zemin hazırlamamış, aynı zamanda Müslümanlar adına hareket ettiğini düşünen DEAŞ, Eş-Şebab vb. terör gruplarının taraftar toplamasına da aracılık etmiştir. Bu terör gruplarının eylemleri, zamanla sosyal medyada i̇slamofobik paylaşımların üretilmesine de kaynaklık etmiştir (Abbas, 2019). İslam adına hareket ettiğini öne süren ve bu savı destekleyici hiçbir tutarlı delil bulundurmayan illegal örgütler, İslamofobik eylemlere karşı direniş göstermiş gibi görünse de en nihayetinde yaptıkları eylemlerle, sosyal medyada yeni İslamofobik fikirlerin üremesine neden olmuştur.

İlk dönemlerde internetteki birtakım web sayfalarıyla gerçekleştirilen İslamofobik eylemler, sosyal medyayla yeni bir mecraya taşınmakla kalmamış daha da yaygın hale gelmiştir. Hatta belirli dönemlerde sıradan kişiler dışında, politikacılar da kendi ülkelerinde yeni seçmen kitleleri kazanmak veya gündeme gelmek adına sosyal medya araçlarında İslamofobik paylaşımlarda bulunmuştur. Bu yola tevessül edilmesindeki asıl maksat; bir taraftan yeni siyasi taraftarlar kazanmak diğer taraftansa aynı minvalde düşünen mevcut seçmen kitlesini bilhassa da kemikleşmiş tabanını korumaktır. İngiltere'de İşçi Partisi tarafından başlatılan İslam'ın Britanya topraklarından çıkartılmasına yönelik kampanya, burada örnek olarak verilebilir (Allen, 2010a). Bu tarz kampanyaların sosyal medya platformları üzerinden gerçekleştirilmesi, bu medya ağlarının İslamofobik tutumların sergilendiği bir araca dönüşmesine yol açmıştır.

Müslümanların gündelik yaşamdaki dini ritüellerine karşı olan kesim, sadece geleneksel yolların efektif kullanılmasıyla değil aynı zamanda sosyal medyadan faydalanarak da İslam dinine inanan kesime saldırmaktadır (Andre, 2016). Sosyal medyanın katılım ve paylaşım kültürü, bu tür eylemleri organize etme ve taraftar toplamada önemli bir vazife görmektedir. Sosyal medyada sadece kişisel hesaplardan İslamofobik paylaşımlar yapılmamakta, aynı zamanda ağa bağlı birçok sözlük ve wiki sayfaları kullanılarak da İslamofobik içerikler üretilmektedir. Google tarayıcısı üzerinden “islam” kelimesi aratıldığında, karşımıza çıkan ilk sayfaların başında Vikipedi olmaktadır. Sayfada İslam ve Müslümanlar hakkında yer alan bilgiler arasında, i̇slamofobik söylemlerle yetinmeyip onları karalamaya dönük ifadelere de yer verildiği, bunların dışında kaynağı verilmeyen veya kaynağı İslam'ın ana eserlerine dayanmayan bilgilerle İslam dini ve mensuplarının okuyuculara tanıtıldığı görülmektedir (vikipedi, t.y.).

Sosyal medyada İslamofobik paylaşımlarla neredeyse her mecrada karşılaşmak mümkündür. Bazı platformlar sadece kendi grup üyeleriyle erişimi sınırlayarak bu eylemleri gerçekleştirirken, bazıları da herhangi bir erişim sınırı getirmeyerek kamuya açık bir biçimde İslamofobik içerikleri ve yazışmaları paylaşmaktadır. Facebook özelinde gerçekleştirilen bir çalışmada; özellikle Müslüman toplulukları hedef alan Facebook gruplarının kurulduğu, bu grupların ana gayesinin ise Müslüman kesime yönelik stereotipler veya sanal şiddet unsurları yaymak olduğu tespit edilmiştir. Aynı çalışmada, Facebook duvarlarında bulunan yazı ve fotoğraflarda; sıklıkla Müslüman kadınların ülke güvenliği için büyük bir tehdit oluşturduğu, Müslümanların terörist olarak görüldüğü, tarih boyunca yapılan haçlı seferlerinin haklılığına vurgu yapıldığı, Müslümanların ülkelerinden çıkarılmasını ve Müslümanların tecavüzcü olduğuna dair karalayıcı yakıştırma, muzır benzetme ve nitelemelerin çok sık bir biçimde istemli ve hedef göstererek paylaşıldığı tespit edilmiştir (Awan, 2016, s. 10). 
Ana akım medyaya alternatif yayın yapma imkânı tanıyan YouTube'da da İslam dini ve mensuplarına yönelik karalayıcı, lekeleyici ve tahkir edici duygu ve tutumlar içeren yorumlar bulunmaktadır. Yapılan yorumlarda; hoşgörüsüzlük, şiddet, göç, komplo teorileri ile bu içeriklere karşı doğal olarak kendi inancını müdafaa refleksi geliştiren kitlelerin görüşlerinin sıklıkla paylaşıldığı belirlenmiştir (Yusha'u, 2015, s. 182). YouTube'da kullanıcıların içeriklere yaptıkları yorumlar dışında, İslamofobik görüntü, yazı veya sesleri içeren videolar da paylaşılmıştır. Bu tür videolarda; İslam dininin bulunduğu coğrafyaların yakın gelecek için bir tehdit oluşturduğu, Müslümanların gayrimüslimleri İslam dinini kabul etmesi için çeşitli aldatmacalara başvurabileceğini ve Müslümanların ana hedeflerinin tüm dünyayı İslam'ın belirlemiş olduğu kıstaslarla tek elden yönetmeyi hedeflediğine dair fikirler paylaşılmıştır (Tsuria, 2013, s. 223). Komplo teorileri dışında, bilhassa Müslüman kadınların giyim tarzlarına yönelik cinsiyetçilik temelli İslamofobik videolar da bu mecrada yer bulmuştur (Shirin, 2012). Bu tarz içerikler daha çok ana akım medyasında popülist yaklaşımlarla desteklenerek üretilmiştir (Cherribi, 2011, s. 47). Bu bağlamda; gündemde yer edinen bir konunun İslam dini eleştirisi üzerinden saptırılmış ve kasıtlı olarak eksik bırakılmış yorumlamalar üzerinden değerlendirilmesi, aslında popüler olmak ve tıklanma pahasına, İslamofobik fikirlerin sosyal medya platformlarında şuurlu bir biçimde üretildiğini ortaya koymaktadır.

Facebook ve YouTube özelinde yapılan bu İslamofobik paylaşımların dışında, başta Avrupa'daki ülkeler olmak üzere, siyasi partiler tarafından desteklenen cami inşaatlarını engelleme kampanya ve girişimleri yine sosyal medya platformları kullanılarak kamuoyu oluşturulmaya çalışılmıştır (Allen, 2010b). Bunun dışında son yıllarda Suriye ve Afgan göçmenlerin Avrupa kıtasına geçme isteği, Avrupa'da yeni İslamofobik söylemlerin politika ve halk tarafından ileriki yıllarda üretilmesine zemin oluşturabilir. Nitekim Gorman ve Culcasi'nin (2021, ss. 178-179) Amerika Birleşik Devletleri, Batı Virginya eyaletinde gerçekleştirdikleri bir araştırmada; Suriyeli mültecilerle özelinde İslamofobik tutumların göçmenlerle birlikte arttığını bulgulamıştır.

Twitter özelinde İslamofobik bakışla yapılan çalışmalarda ise yoğun olarak yurtdışındaki politikacılar, belirli medya organlarının yayın/yayımları, ülke içinde yaşanan terör saldırıları ve Twitter'da gündeme getirilen farklı sosyolojik problemlere sıklıkla yer verilmiştir. Yapılan bu çalışmaların sonucunda; özellikle Müslümanlara karşı siber nefret söylemlerinin Twitter kullanıcıları arasında yaygın olarak kullanıldığı bulgulanmıştır (Awan, 2014; Magdy, Darwish ve Abokhodair, 2015; Puschmann, Ausserhofer, Maan, \& Hametner, 2016; Kanbur, 2020; Türkoğlu ve Türkoğlu, 2021). Tüm diğer sosyal medya mecralarda olduğu gibi Twitter özelinde yapılan araştırmalarda da daha çok yurtdışındaki Twitter hesaplarında gerçekleşen İslamofobik paylaşımlara odaklanılmıştır. Türkçe içerikli Twitter hesaplarına ilişkin herhangi bir çalışmaya rastlanılmamıştır. Diğer Müslüman ülkelerdeki Twitter hesaplarında gerçekleşen İslamofobik durumlara yoğunlaşan çalışmaların ise oldukça sınırlı bir sayıda olduğu gözlemlenmiştir.

Sosyal medya uygulamalarının her bir platformu, kendine has özellikleri barındırmaktadır. Bu platformların tefrikalarına rağmen, İslam'ın toplumsal düzeni zedelediği, yapılan İslamî ritüellerin irticai faaliyeti olarak lanse edildiği, İslamî yaşamı benimseyen ve bu noktada giyinen kesimin sosyal yaşamda yeri olmadığına yönelik itibar suikastı içeren İslamofobik fikirlere neredeyse her sosyal medya platformunda karşılaşılmaktadır (Temel, 2020, s. 53). Müslüman kimliklere yönelik gerçekleştirilen bu İslamofobik tavırlardan dolayı, sosyal medyayı deneyimleyen yeni nesil Müslümanlar, bu tarz söylemlere cevap vermek ya da bu söylemlerin dışında kendilerini konumlandırmak adına karşı paylaşımlar yaparak kendilerini müdafaa etmektedir (Saeed, 2016, s. 154). Böylece her iki kesim, karşı tarafı kendince ikna etme dili kullanarak anti-i̇slamofobist söylemlere girişmektedir. Bu durum beraberinde, karşılıklı olarak belli bir ölçüde siber zorbalığı da getirebilmektedir.

\section{Metodoloji}

Üç semavi dinin (İslamiyet, Hristiyanlık ve Yahudilik/Musevilik) inancında yegâne ve tek olarak adlandırılan yaratıcıya inanılmaktadır. Her bir inançta yüce yaratıcıya farklı isimlerle (Allah (c.c.), God/Tanrı ve YHVH/ Yehova) seslenilmektedir. Araştırmada, üç semavi din tarafından farklı adlarla ifade edilen yaratıcıya ve Müslümanların maddi ve manevi değerlerine ilişkin Twitter üzerinden yapılan İslamofobik paylaşımlar irdelenmiştir. Konu bu yönüyle sadece İslamofobiyle sınırlı kalmayıp diğer semavi dinlerin de ilgi alanına girecek güncelliğe sahiptir. Çalışmada amaçlanan; makro anlamda sosyal medya, mikro düzeyde ise Twitter özelinde gerçekleşen İslamofobik görünüm, paylaşım ve meşrulaştırma çabalarını Twitter üzerinden İslamofobik paylaşımlar yapan @CenabiAllah hesabı üzerinden ortaya koymaktır. Araştırma, Twitter özelinde gerçekleştirilen İslamofobik çalışmalardan iki önemli fark içermektedir. İlki; İslamofobik paylaşımları İslam dininin benimsendiği bir ülkede araştırması, ikincisi ise İslamofobinin daha önceki çalışmaların ortaya koyduğu nefret söylemi içerisinden çıkartarak (Vidgen ve Yasseri, 2020, s. 75) bu söyleme konu olan anti-islam/Müslüman fikirlerin yoğunlaştığı diğer ilişkili alt başılıkları da tespit etmesidir.

Nitel araştırmaların amaçlı örnekleme daha uygun olması nedeniyle, çalışmada amaçlı örneklemin ölçüt tipinden hareketle örneklem belirlenmiştir (Forman, Creswell, Damschroder, Kowalski ve Krein, 2008, s. 
767; Büyüköztürk, Kılıç Çakmak, Akgün, Karadeniz ve Demirel, 2018, ss. 94-95). Araştırmada incelenen Twitter hesabının seçilmesinde takipçi sayısı baz alınmıştır. Söz konusu araştırma örneklemine giren Allah (c.c.) ismiyle açılan Twitter hesabı; @CenabiAllah menşınını kullanmakta ve 222,2 Bin takipçi sayısıyla Türkçe içerikli paylaşımlar yapmaktadır. Araştırmada ilgili hesabın 25.10.2020 - 03.01.2021 tarihleri arasındaki tweetleri nitel araștırma desenleri içerisinden vaka çalıșması desenine göre incelenmiștir (Yin, 2018). Söz konusu hesabın 03.01.2021 tarihinden 24.06.2021 tarihine kadar paylaşımlarına ara verdiği, 25.06.2021 tarihi itibariyle yeni tweetler paylaştığı görülmüştür. İlgili hesap Ekim 2021'de kapatılmış, fakat bu kez de @cenabiaallah2 hesabı üzerinden paylaşımlarına devam etmiştir.

Araştırmada zaman ve maliyet kısıtlıkları göz önüne alınarak ilgili hesabın 25.10.2020 - 03.01.2021 tarihleri arasındaki metinsel tweetleri ve bu tweetlere takipçilerin yaptığı yazılı etkileşimlerle çalışma sınırlandırılmıştır. Söz konusu tweetlere ilişkin gerçekleştirilen içerik analizinde hem veri deseninden çıkan yeni kategoriler hem de daha önce sosyal medya ve İslamofobi konusunu işleyen çalışmalardan hareketle kodlamalar yapılmıştır (UenaL vd., 2021; Temel, 2019; Awan, 2016; Yusha'u, 2015; Kumar, 2007). Kodlama süreci; sözcük ve cümleler esas alınarak iki düzeyde gerçekleştirilmiștir (Yıldırım ve Şimşek, 2011, s. 233). Kodlama süreci sonucunda kategoriler kendi içinde alt kategorilere daha sonraki süreçte ise ayrıştırma yoluyla bu kodlanmış veriler, belirli temalar altında birleştirilerek toplatılmıştır (Schreier, 2012, ss. 59-65). Alan yazında önerilen (Kirk ve Miller, 1986; Neuendorf, 2002) kadlayıcılararası uyum testiyle söz konusu kodlamaların literatürce belirlenen (Kassarjian, 1977, s. 14; Graham, Milanowski ve Miller, 2012, s. 7) yüksek güven aralığına denk düștüğü bulgulanmıştır (Cohen's Kappa= \%86,2). Mayring (2000) ve Schreier (2012)'den hareketle geliștirilen aşağıdaki diyagramla; araştırmanın amaç ve sorusu, veri setinin toplama, kodlama ve raporlaştırma süreçleri adım adım çizilmiştir.

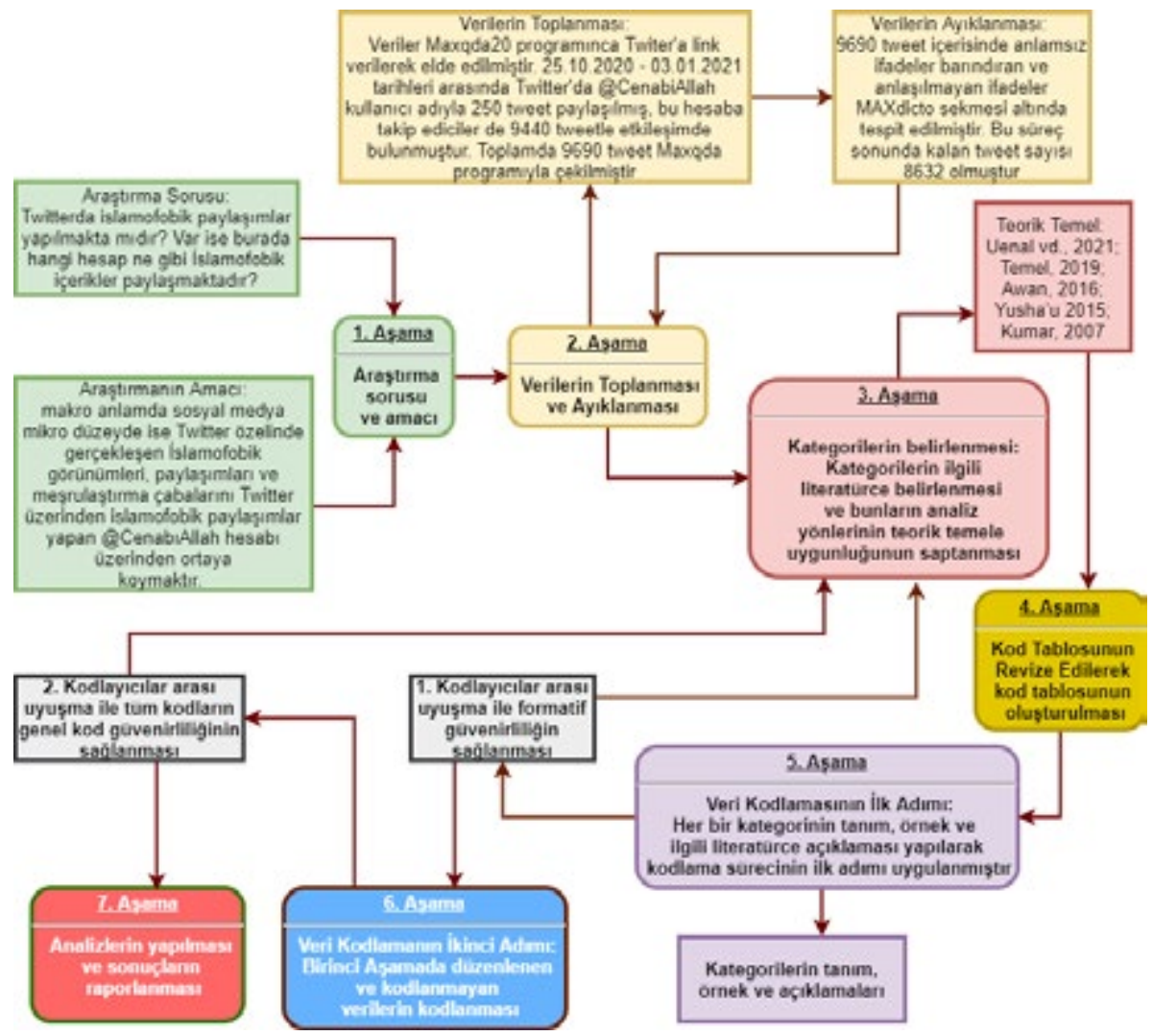

Şekil 1. Veri Setinin Toplama, Kodlama ve Raporlaştırma Aşamaları (Mayring, 2000; Schreier, 2012)

\section{Araștırma Soruları}

Sosyal medyada islamofobik paylaşımları ele alan bu çalışmada, aşağıda belirtilen sorulara cevap aranmaya çalışılmıştır:

1. Twitter'da Allah (c.c.) adıyla çevrimiçi tweetler atan hesap hangi konularda paylaşımlar yapmaktadır?

2. @CenabiAllah hesabını takip edenler hangi konularda bu hesaba cevap yazmaktadır?

3. @CenabiAllah hesabı ve onu takip edip etkileşimde bulunanlar arasında İslamofobik konularda farklılık ve benzerlikler görülmekte midir? 

tirmektedir?

4. @CenabiAllah Twitter hesabı ile bu hesabı takip edenler hangi etiketlerle paylaşımlarını gerçekleş-

5. İslamofobik paylaşım yapan Allah (c.c) Twitter hesabına kullanıcıların verdiği karşıt tepkiler nasıldır?

6. İslamofobik paylaşımlar ile diğer tüm kategoriler arasında nasıl bir ilişki söz konusudur? Bu ilişkide öne çıkan hususlar nelerdir?

\section{Bulgular}

Araştırmaya konu olan hesabın profil sayfasına ait bilgileri veren aşağıdaki görselde; Yüzüklerin Efendisi filminde önemli bir karakter olan Gandalf'ın bir sahnede durduğu an ve söylem (YOU SHALL NOT PASS) profil resmi olarak kullanılmıştır. Twitter hesabını yöneten kişi/kişiler kendi kimliklerini ifşa edecek herhangi bir bilgiye profil sayfasında yer vermemiştir. İlgili Twitter hesabının profil görünümünde ilk bakışta bile İslamofobik öğelerin olduğu göze çarpmaktadır. Gerek Allah lafzı ile Cenabı Allah nitelemesini hesap adı olarak kullanması gerekse de konum (Her yer) ve ‘Kızıldeniz’i ikiye Yardırtan’ cümlesiyle İslami değerleri tiye aldığı ilk bakışta anlaşılmaktadır. 2013 yılında açılan hesabın ulaşılan ilk tweeti 31.05.2013 tarihli; "Taksimdeki Direniş Büyüyor. Onbinler Faşizme karşı yürüyor. \#direngeziparki” etiketli paylaşım olmuştur. Söz konusu hesabın geçmişe yönelik bazı tweetlerini sildiği, özellikle 2018 yılından sonra İslamofobik paylaşımlara ağırık verdiği gözlemlenmiştir. Hesabın Twitter'daki profil görünümü resim 1'de verilmiştir.

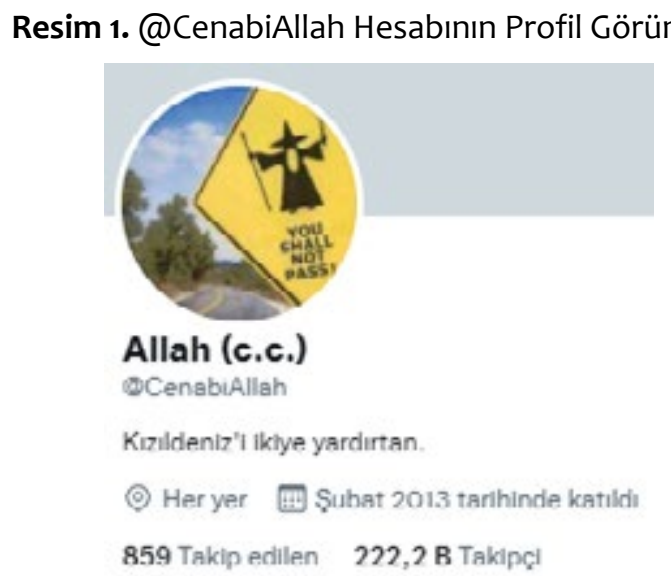

Allah (c.c.) isimli sayfa, yurtdışında God (@TheTweetOfGod) kullanıcı adıyla 6.2 milyon takipçisi bulunan Twitter hesabını ilham alarak hareket etmektedir. Ingilizce tweet atan bu hesap, yoğun olarak Hristiyanlık inancını hedefe koyarak dini değer ve inanışları mizah görüntüsü altında ötekileştirmektedir. @CenabiAllah hesabı belli aralıklarla takipçilerine gündem, siyaset ve İslamiyet hakkında sorular sormaktadır. Daha sonra verilen cevaplara göre bir sonraki paylaşımını kurgulayarak takip edicilerine bunu paylaşmaktadır. Söz konusu sayfanın içeriklerini retweet eden veya ona cevap yazan hesapların Twitter hesaplarındaki profil bilgisinde (fotoğraf, profil yazıları ve duvar yazıları) genellikle LGBT ağırlıklı mesaj ve görseller kullanıldığı göze çarpmıştır.

Araştırma Sorusu 1: Twitter'da Allah (c.c.) adıyla çevrimiçi tweetlerde bulunan hesap, hangi konularda paylaşımlar yapmaktadır? tadır?

Araștırma Sorusu 2: @CenabiAllah hesabını takip edenler hangi konularda bu hesaba cevap yazmak-

Araştırma Sorusu 3: @CenabiAllah hesabı ve onu takip edip etkileşimde bulunanlar arasında İslamofobik konularda farklılık ve benzerlikler görülmekte midir?

@CenabiAllah hesabı ve onu takip edenlerin tweetlerinde; İslamofobi, kendini nitelendirme, dil, politika, diğer semavi dinler, propaganda, sesleniş, etkileşim ve kadınları aşağılama temalarında ortak paylaşımlar yapılmıştır. Allah (c.c.) kullanıcı adındaki hesap, haber kaynakları; takip edicilerse, ırkçılık temasında farklıık oluşturmuştur. Söz konusu hesabın kendine ait tema ve kategorileri Şekil 2'de, takip edicilerin bu hesaba yönelik yaptığı yorumlar ise Şekil 3'de gösterilmiştir. 
Her bir temaya ait kategoriler değerlendirildiğinde Twitter hesabı ve bu hesabı takip eden takipçilerin paylaşımlarında öne çıkan kategori ve başlıklar şu şekilde sıralanmıştır': İslamofobik konularda; dini değer ve söylemler \%59,4 - \%17,4 , Kur'an-ı Kerim \%12,5 - \%10,3, Müslümanlar \%8,3 - \%0,5 melekler \%4,2 - \%0,8, Allah’ı küçümseme 3,1 - \%3,3, ahiret inancı \%3,1 - \%4,7, peygamberler \%2,1 - \%0,7, Günah Kavramını Alaya Alma \%2,1 $\% 29,4$, Allah'ın vasıfları \%2,1 - \%5,7, farzlar -namaz,oruç vb.- \%1,0 - \%0,2, Arapça \%1,0 - \%10,4 ve dini kurum ve şahıslar hakkında \%1,0 - 16,4 oranında tweet atılmıştır. Takip ediciler hesap dışında ayrıca sarık ve sakal \%0,1 ile İslami isimler \%o,1 noktasında da İslamofobik paylaşımları olmuştur. Sadece İslam dini değil aynı zamanda Hristiyanlık $(\% 83,3$ - \%97,2) ve Musevilik $(\% 16,7$ - \%2,8) değerlerinin tahkire uğradığı paylaşımlar da bulunmuştur.

İlgili hesap ve onu takip edenlerin daha çok İslam akaidi ve Müslümanlar üzerinden hareket ederek İslamofobik paylaşımlarda bulunduğu bulgulanmıştır. İslam dini dışında tek ilahlı diğer iki inancın da burada fobik söylemlere maruz kaldığı görülmektedir. Söz konusu İslamofobik teması altında atılan bazı tweetler ile bu tweetlere kullanıcıların verdiği yanıtlar orijinal halleriyle aşağıda verilmiştir.

Hesap: Dört kitap gönderdim çünkü bu da benim mizah anlayışım; Artık kilo verme rejimini de ibadetten sayıyoruz. Her verdiğin kilo başına 1000 sevap points kazanıyorsunuz; Bugün benim için ne içtiniz; gece içilen içkilere günah points yazmıyorum. Bendensiniz; İşiniz mikosya kaldı; Allah'ın Allah belasını versin; Biz de kitaplarımızda 3 tane "ki” kullanıyoruz: 1- Bağlaç olan ki 2-Ek olan ki 3-Şüphesiz ki; Bugün içilen içkilerin günahını diyanete yazıyorum; O nasıl bir duaydı lan yataktan fırladım; Günaydın çamurdan yarattıklarım; Rakı için buz yağdırdık daha ne istiyorsunuz; Günaydın kulişkolar; Kendini Allah diye tanıtıp para karşılığında seni peygamber yapacağım diyenlere itibar etmeyiniz!; Sen ne güzel ol’muşsun elime sağlık.

Takipçiler: Niyet ettim spora başlamaya, Allahım sen kabul et yarabbim; Mikaile çok içirme, içince sapıtıyor; Özellikle son kitap bizi hiç güldürmedi; O kadar kitap indirmiş/göndermiş, ondan daha iyi yazarlık dersi veren olmaz. Gerçi son kitabında ciddi kurgu hataları, tekrarlar, kopukluklar ve yüzeysel karakterler var ama neyse; Yılbaşında içtiklerimizide diyanete yazarmısın ulu manitu. Ona göre içelim; Inşallak cünabettin Hz.; Paso yeni dinler gönderiyorsun, bir sürü din oldu yeryüzünde sanki siyasi parti gibiler, hep onların iktidarı sana ulaşıp cennet ölümsüzlük huriler falan ile ödüllendirecek diye vaat ediyorlar. Sana göre en kârlı din hangisi?; 120 bin peygamber. Her biri ortalama 30 yıl yaşasa, etti sana 3 milyon 600 bin yıl. 2.5 milyon yıl önce Homo cinsi görüldü. O zaman ilk peygamber taraklı sürüngen miydi? @CenabiAllah açıklama bekliyoruz; Bu akşam da içtim yüz-ü hürmetine. Günahını hangi iban'a göndereyim?; Günahları yobazlara yazarsan bende iki duble atarım.(Sevmediğim halde); @CenabiAllah Rabia isareti yapanlari mi aliyorsun herkezi sen yaratin simdi adam seciyon $2 \mathrm{dk}$ allah ol mk.

Her iki hesabın ortak temasında bulunan politika başlığında (Bkz. Dipnot 1) iç gündem \%75 - \%11,1, Selahattin Demirtaş \%9,1 - \%41,1, Cumhurbaşkanı Recep Tayyip Erdoğan \%6,8 - \%6,5, Devlet Bahçeli \%4,5 - \%2,8, Ömer Faruk Gergerlioğlu \%2,3 - \%38,2 ve Kemal Kılıçdaroğlu \%2,3 - \%0,3 oranında yer bulmuştur. Twitter kullanıcılarının paylaştığı politik içerikli tweetlerin büyük bir bölümü, HDP’ye yönelik olmuştur. Söz konusu bu tweetlerde daha çok Demirtaş’a yönelik pozitif bir vurgu yapılırken, Erdoğan ve Bahçeli hakkında ise negatif bir tavrın olduğu belirlenmiştir.

Yapılan analizlerde Allah (c.c.) hesabı ve takip edicilerin tweetlerinde dil teması altında dört kategori keşfedilmiştir. Buna göre; alaya alma \%98,5 ve mizah \%1,5 @CenabiAllah hesabında bulgulanırken, takip ediciler de ise alaya alma \%74, nefret dili \%12,7, küfür/hakaret \%8,6 ve mizah \%4,8 oranında Twitter paylaşımlarında yer bulmuştur. ilgili tweetlerde hesap tarafından takipçilere kullarım; takip ediciler ise hesaba Allah'ım $(\% 50,2)$ ve Tanrım $(\% 49,8)$ ifadeleriyle seslenmiştir. Öte yandan söz konusu söylemlerde bazı konular bilinçli bir biçimde propaganda edilmiştir. Ateizm $(\% 66,7)$ ve laiklik $(\% 33,3)$ konuları hesap tarafından propaganda edilirken, takip ediciler tarafından ateizm $(\% 13,9)$ dışında, komünizm $(\% 44,4)$ ve PKK propagandası $(\% 41,7)$ içeren içerikler de Twitter'da paylaşılmıştır.

Araştırmaya konu olan hesap, Twitter'da kendini yaratıcının bir vasfına büründürerek paylaşımlarda bulunmuştur. Burada Allah'la kendini denk tutma \%64,5, dünyayı yönetme \%11,8, yaratma \%8,6 ve kâinatı yönetme \%4,3 düzeyindeyken, beșerî vasıflarını yansıttığı paylaşımlar ise \%10,8 oranında olmuştur. @CenabiAllah Twitter hesabı, yoğun olarak paylaşımlarında kendini üç semavi dinin ortak bir argümanı olan yaratıcı/ilah şeklinde konumlandırmıştır.

Sayfayı takip eden kesimin ulaşılabilen profil sayfalarında, kendileri için; Atatürkçü $(\% 75)$, ateist $(\% 12,4)$, insan $(\% 5,9)$, doğa sever $(\% 3,2)$ ve kadın $(\% 3)$ nitelemelerini sıklıkla kullanmıştır. Takip ediciler, @CenabiAllah hesabına yönelik tweetlerde istekte bulunma $(\% 56,1)$, soru sorma $(\% 11,9)$, onaylama $(\% 11,4)$, şikâyet etme 
$(\% 9,9)$, selamlama $(\% 9,6)$ ve destekle $(\% 1,0)$ etkileşimde bulunurken, hesap ise soru sorma $(\% 44)$, yazılan tweetleri cevaplama (\%16), retweet (\%16), benzer sayfalardan link verme (\%12) ve etiketle gündem belirleme (\%12) ile bu etkileşimi gerçekleştirmeye çalışmıştır.

Kamuoyu önündeki kadınlara veya eylemlerine yönelik aşağılayıcı tweetler hem hesap hem de takip ediciler tarafından paylaşılmışıı. Hesap tarafından atılan bir tweette; "Şu üç kadın tipini cehenneme almayı düşünüyoruz 1- spor konuşan 2- ünlü kişilere aşık olan 3- twitter'da story atan" ifade edilirken, takip edicilerse bu tweete, Emine Erdoğan ve Hilal Kaplan özelinde, kadın onuruna yakışmayacak tabir ve betimlemeler kullanarak cevap yazmıştır. Erdoğan ve Kaplan hakkında atılan tweetlerde sıklıkla politik söylemlerden hareket edilerek aşağılayııı tweetler atılmıştır.

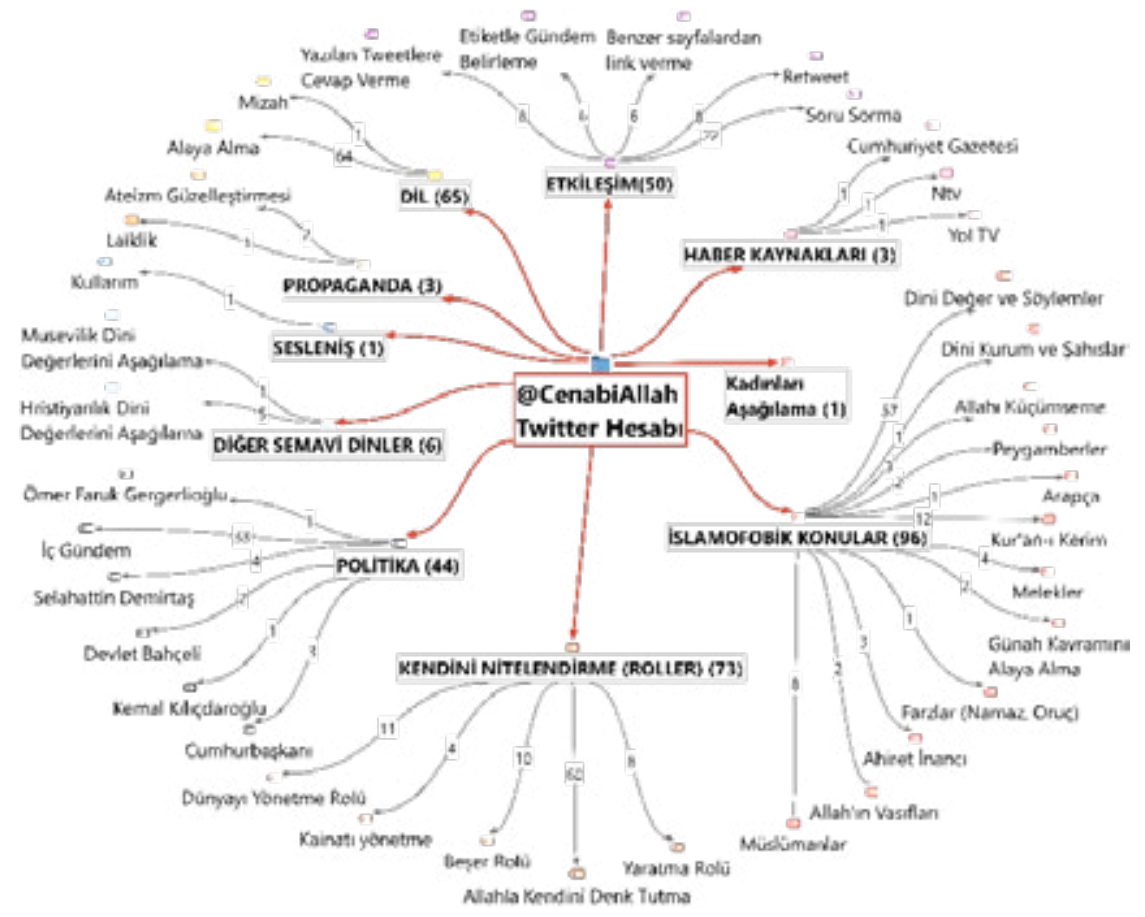

Şekil 2. @CenabiAllah Twitter Hesabının Paylaşımlarına Dair Tema ve Alt Kategoriler

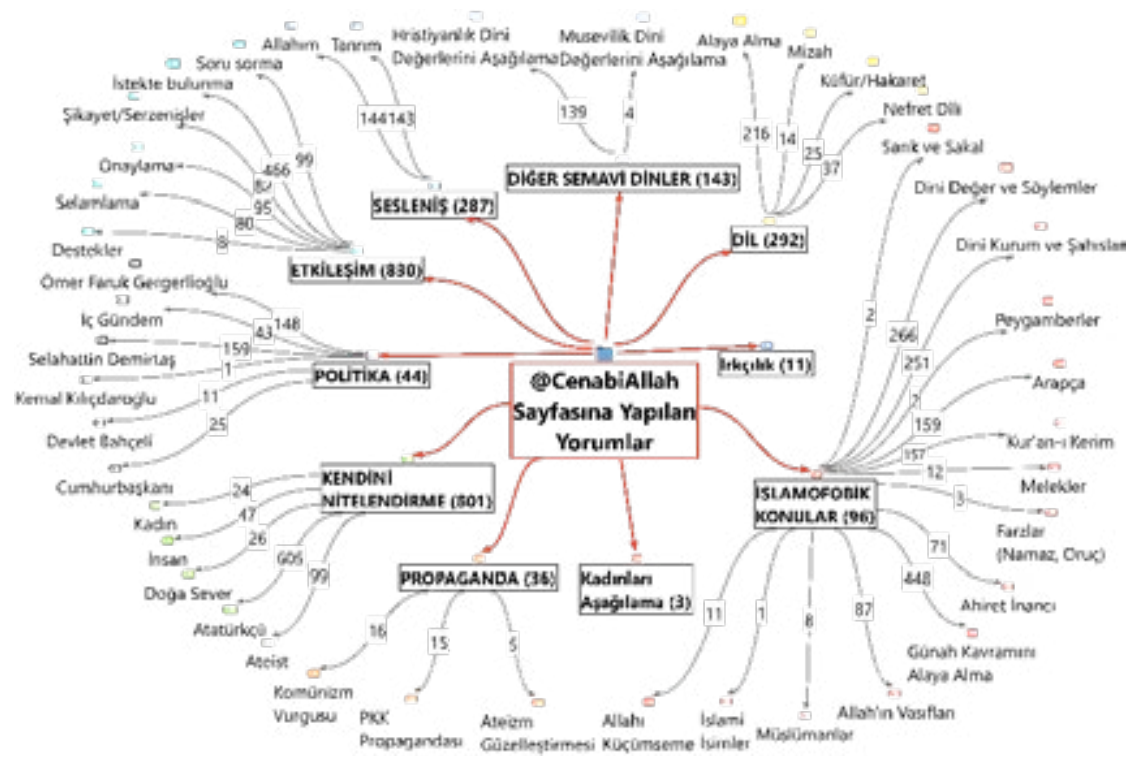

Şekil 3. @CenabiAllah Twitter Hesabını Takip Edenlerin Tweetlerine Dair Tema ve Alt Kategoriler

Araştırma Sorusu 4: @CenabiAllah Twitter hesabı ile bu hesabı takip edenler hangi etiketlerle paylaşımlarını gerçekleştirmektedir? 


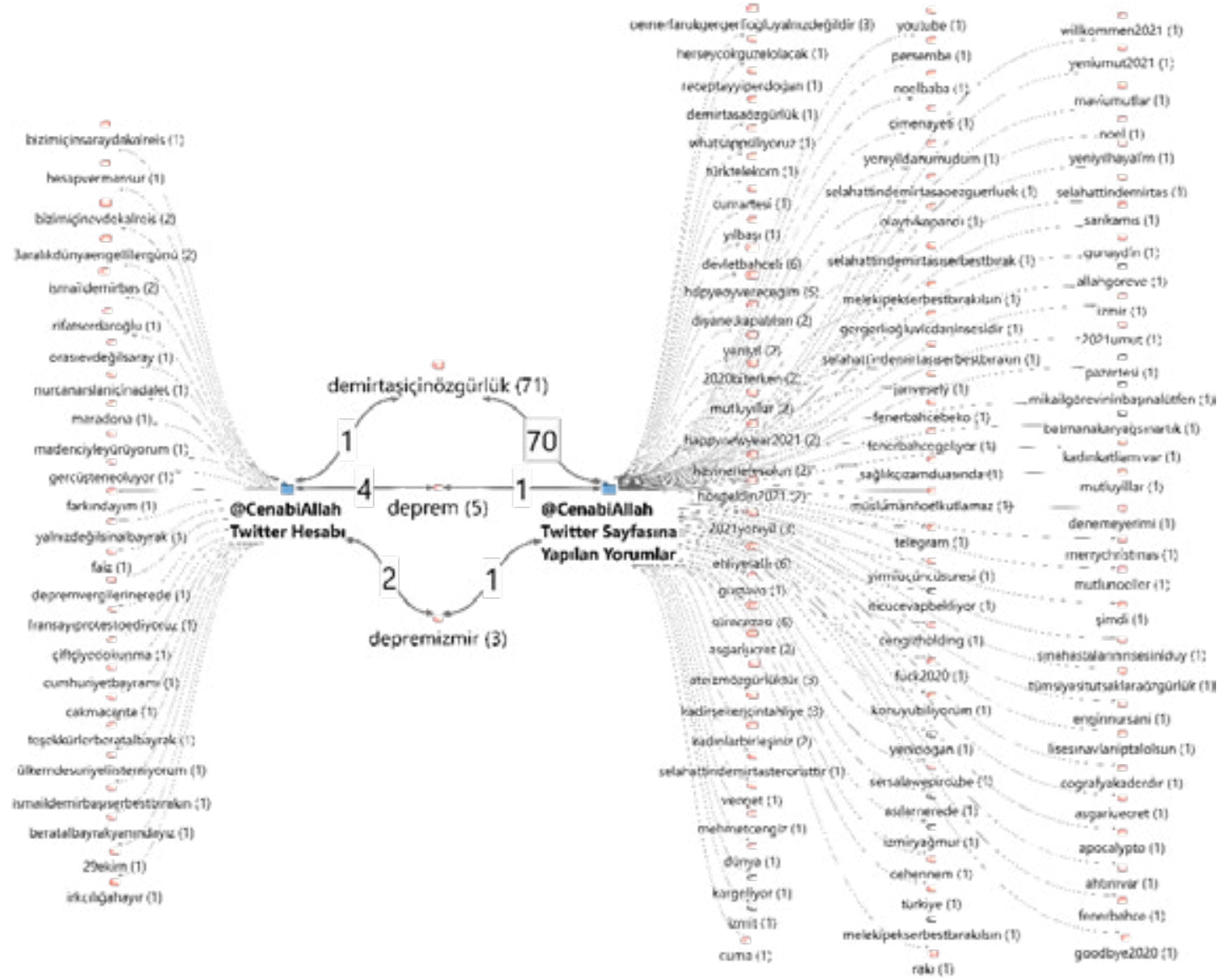

Şekil 4. @CenabiAllah Twitter hesabı ile bu hesabı takip edenlerin Kullandığı Etiketler (\#)

Twitter üzerinden İslamofobik paylaşımlarda bulunan Allah (c.c.) kullanıcı adlı hesap ile bu hesabı takip edenlerin yazdığı bazı tweetlerde etiketleme (\#) yoluna başvurulmuştur. Takip ediciler ve hesap tarafından üç etiketin ortaklaşa kullanıldığı (\#demirtaşiçinözgürlük, \#deprem ve \#depremizmir) diğer etiketlerinse birbirlerinden farklılık arz ettiği görülmüştür. \#demirtaşiçinözgürlük (71) etiketi tüm etiketler içinde en sık paylaşılan hashtag olmuştur.

@Cenabi Allah hesabı; Twitter'daki paylaşımlarında sıklıkla politik konuları ilişkilendirecek şekilde tweetler paylaşmıștır. Burada sıklıkla hükümeti hedef alan ve hükümeti eleştiren gündemdeki etiketlerden yola çıkarak paylaşımlarda bulunmuştur. Takip ediciler bu iki başlık dışında; Selahattin Demirtaş, Devlet Bahçeli, Ekrem İmamoğlu gibi siyasi karakterle Twitter'da gündem olan konuların etiketleriyle ilgili hesaba cevaplar yazmıştır. Söz konusu hesap ve takip edicilerin tweetlerinde kullandığı etiketler şekil 4'de verilmiştir. nasıldır?

Araştırma Sorusu 5: İslamofobik paylaşım yapan Twitter hesabına kullanıcıların verdiği karşıt tepkiler

Yapılan İslamofobik paylaşımlara Twitter kullanıcıları dört başlık altında karşıt tepkilerde bulunmuştur. Bu tepkilerin gösterildiği şekil 6'da sağduyulu çağrılar \%56 oranına sahipken, bunu hesaba yönelik küfür/ hakaret $(\% 22)$, ayetle uyarma $(\% 19,5)$ ve soru sorma $(\% 2,4)$ takip etmiştir. Daha çok Müslüman olan kesim tarafından karşıt tepkilerin yazıldığı tweetlerde; @CenabiAllah hesabının yaptığı paylaşımlara cevap vermekten ziyade kullanıcılar yapılanın insanî bir davranış olmadığının altını çizmiştir. Aşağıda Twitter kullanıcılarının @ CenabiAllah hesabına yönelik karşıt tepkilerini ifade eden tweetler bulunmaktadır.

Seni yaradan allaha senin adına af dilicem; Valla yazık sizin gibi insanlara; Şu an bir sürü şey demek isterdim ama adabım el vermiyor Rabbim ıslah etsin sizi ve sizin gibileri; Şöyle, benim değerlerime saygısızlık yapılmadığı sürece susarım, bende saygı gösteririm. Fakat saygısızlık yapılırsa konuşurum, o yüzden çevremdeki insanlar saygısızlık yapmadığı için susardım; @CenabiAllah Yani bu biraz fazla saygısız olmuş hiç etik değil; Senide senin sahibinide sana kemik atanida besleyeninde senden olanida senden birlikte olaninda yedi ceddini gelmisini gecmisini .......; Sen bir soysuzsun; Lan geri zekalı ahmak sen kendini ne zanediyorsun iblisin yavuklusu Allah er 
geç belanızı verecek beyinsiz Ahmaklar; Sonra kötülük yapanların akıbeti, akıbetlerin en kötüsü oldu. Allah'ın ayetlerini yalanlayıp alaya aldılar. (Ya da; "Ayetleri yalanlamaları ve alaya almaları nedeniyle en kötü akıbete düçar oldular.") (30/Rûm 10); Hak kendilerine gelince elbette, onu yalanladılar. Alaya aldıkları (şeyin) haberleri onlara gelecektir. (Neyi alaya aldıklarını anlayacaklar.) (6/En'âm 5); KAÇ INSANI HAKK YOLUNDAN ÇIKARDIĞININ FARKINDA MISIN SEN?

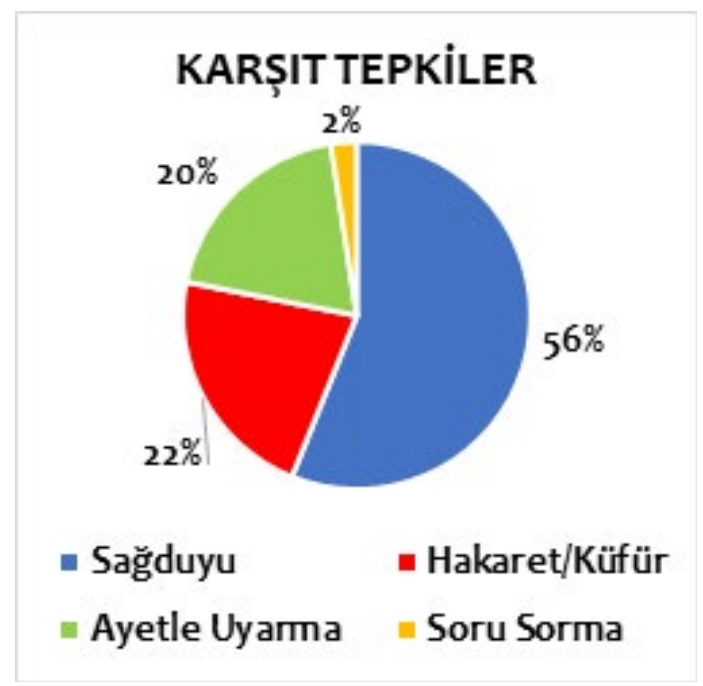

Şekil 5. İslamofobik Paylaşımlara Karşıt Tepkiler

Araştırma Sorusu 6: İslamofobik paylaşımlar ile diğer tüm kategoriler arasında nasıl bir ilişki söz konusudur? Bu ilişkide öne çıkan hususlar nelerdir?

Sadece ilişkili olan konuların analize tutulduğu, ilişki dışında kalan başlıklarınsa analizden çıkartıldığı şekil 6'da gerek takip ediciler gerekse @CenabiAllah hesabı tarafından yapılan İslamofobik paylaşımların daha çok hangi kategorilerle ilişkili olduğu ortaya konulmaya çalışılmıştır. Allah'ın vasıfları, peygamberler, Müslümanlar, melekler, Allah’ı küçümseme ve günah kavramı yoğun olarak alaya alma ile ilişkili bulunmuştur. Ateizm ile ahiret inancı da yine yoğun ilişkiye sahip bir başka İslamofobik başlık olmuştur. Bunların yanı sıra nefret dili, istekte bulunma, soru sorma ve Allah’la kendini denk tutan paylaşımların da İslamofobik paylaşımlarla ilişkili olduğu max maps tarafından ortaya konulmuştur. Tüm bunlar dışında kategoriler arasında daha düşük düzeylerde gerçekleşen ilişki ağları da tespit edilmiştir (Bkz. Şekil 7).

Yapılan ilişki testinde İslam akaidi ve Müslümanlara yönelik fobik paylaşımlar, mizah görüntüsü altında alaya alınarak meşrulaştırılmaya çalıșılmıştır. Öte yandan ateizm fikrini benimseyenlerin fobik içerikli tweetlerinde daha çok ahiret inancıyla ilişkili olacak şekilde paylaşımlar yapılmıştır. Özetle, Twitter'da İslamofobik paylaşımlar; mizah, politika, diğer semavi dinler, medya ve ideolojik fikirlerle ilişkili bir biçimde üretilmiştir. 


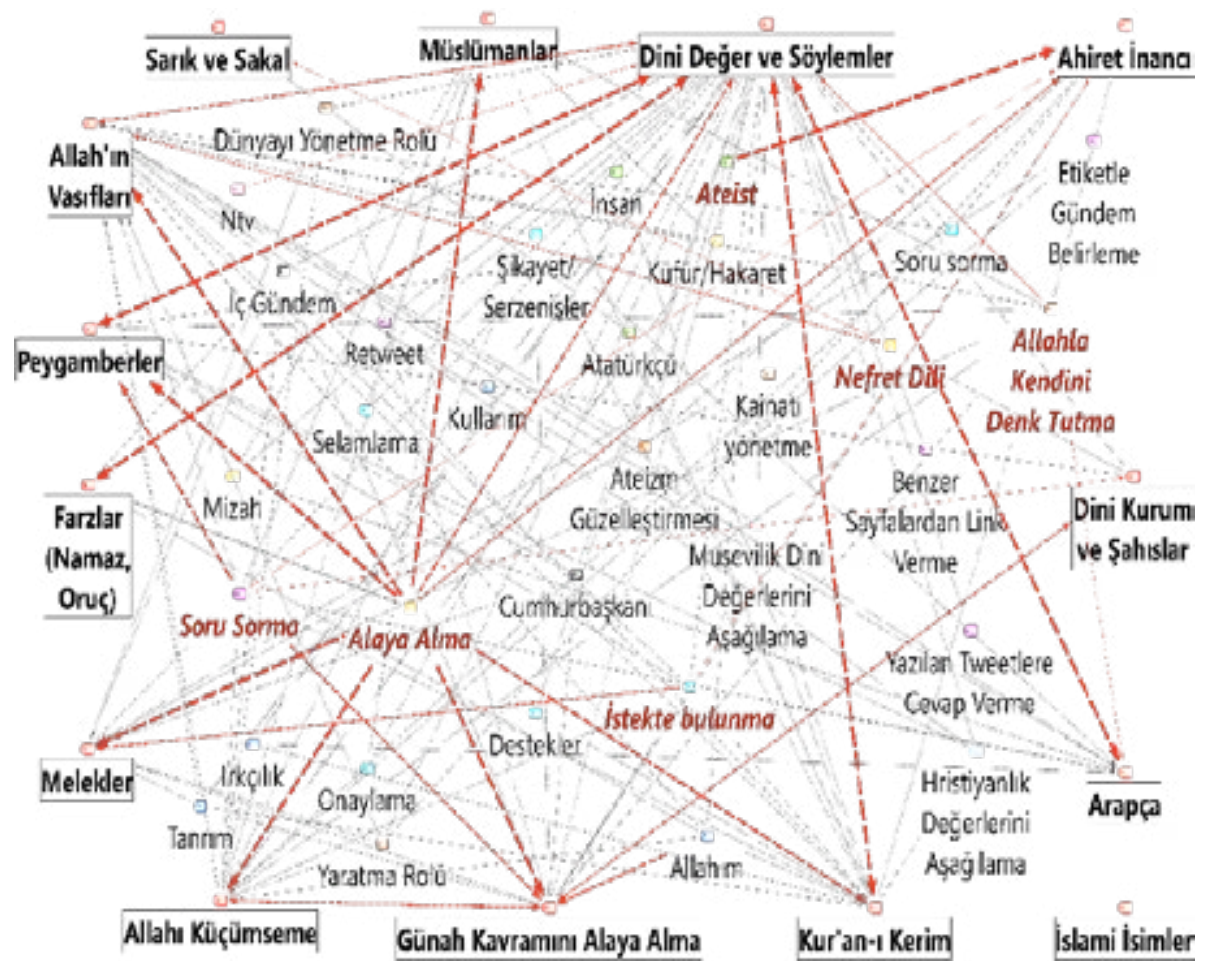

Şekil 6. İslamofobik Paylaşımların ilișkili Olduğu Konular

\section{Sonuç ve Tartıșma}

Ülkemizde geleneksel medya araçlarının yayın(m)larında İslamofobik görünümlere oldukça sık bir biçimde karşılaşılmaktadır. Tıpkı geleneksel medya organlarında olduğu gibi sosyal medya platformlarında da i̇slamofobik söz ve eylemler bilinçli bir biçimde paylaşılmaktadır. İslamofobik durumlar, geleneksel medyanın benimsediği ideoloji veya yayın politikasıyla entegreli bir biçimde gerçekleşirken sosyal medyada ise daha çok birey odaklı bir yapıda bu ötekileștirici dil vücut bulmaktadır. Sosyal medya platformları, İslamofobik fikirlere sahip kişiler için hem bu fikirleri ișmâm etme hem de yeni taraftarlar kazanmada önemli bir rol oynamaktadır. Son yıllarda sosyal medya aracılığılla yapılan bu ötekileştirme dili, geleneksel medya araçlarına kıyasla daha hızlı ve şiddetli bir biçimde yaşanmaktadır. Sosyal medyanın sahip olduğu özellikler bu durumu ortaya çıkartmada belirleyici bir rol oynamıştır.

Milyonlarca kişi tarafından kullanılan Twitter özelinde yapılan bu araştırmada; söz konusu mecrada Türkçe içerikli paylaşımlar yapan @CenabiAllah hesabı ve bu hesabı takip edenlerin paylaşımları nitel anlamda incelenmiştir. 2013 yılında sıradan bir Twitter hesabı görüntüsü altında aç(tır)ılan @CenabiAllah Twitter hesabı, ilk başlarda AK Parti hükümetine karşı politik söylemlerle Twitter'da bir takım içerikler paylaşmıştır. ilgili hesap, zaman içerisinde muhalif çizgiden çıkarak i̇slamofobik düşünceleri benimseyen farklı kesimlerin ortak bir buluşma ve söylem noktası haline dönüşmüştür. Söz konusu Twitter hesabı özelinde yapılan araştırma sonucunda; sosyal medyada İslamofobik paylaşımların kamuoyuna açı bir şekilde paylaşıldığı ve özellikle dini değer ve söylemler, Kur'an-ı Kerim, Müslümanlar, melekler, Allah'ı küçümseme, ahiret inancı, peygamberler, günah kavramını alaya alma, Allah'ın vasıfları, farzlar -namaz, oruç vb.-, Arapça, dini kurum ve şahıslar, sarık, sakal ve İslami isimler başıklarında i̇slamofobik paylaşımların gerçekleştirildiği tespit edilmiştir. ilgili Twitter hesabında yapılan İslamofobik paylaşımlar; İslam dünyasının başlıca değerlerine, kutsallarına, kişiliklerine, bu inancı benimseyenlere/yaşayanlara ve en genel anlamda İslam akaidine yönelik olduğu rahatlıkla ifade edilebilir.

Araştırmada, İslam akaidine ve Müslümanlara yönelik üretilen İslamofobik içeriklerde; i̇slam’a ait değer ve söylemler, peygamberler, melekler, Müslümanlar ve Allah'ın vasıflarına ilişkin tweetler diğer konulara kıyasla daha sık bir biçimde İslamofobik söylemlere maruz kalmıştır. Kullanıcılar, İslam akaidine ilişsin İslamofobik söylemleri mizah görüntüsü altında kurgulayarak Müslüman kesimin dini değerlerini bir nevi itibar suikastına uğratmaya gayret etmiştir. Sosyal medyanın eğlence ve boş zamanların değerlendirildiği bir mecra olması hasebiyle, ilgili hesap ve takip edicilerin manevi konularda bile kendilerini eğlendirme adına Twitter'da hareket etmeye çalıştı̆̆ı görülmüştür. Twitter'da ilahi değerleri bir güldürü unsuru haline getirmeye çalışan kullanıcılar, aynı zamanda Müslüman kesime yönelik nefret dilini de tweetlerinde yer vermiştir. Twitter'da 
İslamofobik paylaşımlarda bulunan kişiler; Twitter'da kendileri gibi düşünen insanları etkilemek ve/veya bu insanların da İslamofobik söylemlerini dile getirmesini teşvik etmek amacıyla mizah ve nefret diline başvurduğu söylenebilir. Kendi inançlarına yönelik yapılan bu tahkirleri görenler veya bu tür İslamofobik söylemlere taraftar olmayan Twitter kullanıcıları ise sağduyu (\%56,1), küfür/hakaret (\%22), ayetle uyarma (\%19,5) ve soru sorma $(\% 2,4)$ ile karşıt tepkilerde bulunmuştur. Bu karşıt tepkilerde daha çok bireylerin inançlarına saygı duyulması konusuna vurgu yapılmıştır. Twitter'da İslamofobik paylaşımlara karşı çıkan kesim ile bu içerikleri üretenler arasında daha çok politik bağlamda karşılıklı düello şeklinde tweetleşmeler meydana gelmiştir. Bu politik içerikler sıklıkla günübirlik siyasi polemikler, liderlerin söylemleri ve iç gündeme ait konular özelinde vuku bulmuştur. Dolayısıyla İslamofobik içeriklerin üretilmesinde politika ve ülke gündeminin oldukça büyük bir etkiye sahip olduğu söylenebilir.

İslamofobik tweetler, sıklıkla iç gündemdeki konuların etiketlenmesiyle kurgulanmıştır. Cumhur İttifakı özelinde yapılan eleştirilerle bu fobik söylemler perçinlenmeye çalışılmıştır. Yine yoğun bir şekilde Selahattin Demirtaş başta olmak üzere HDP taraftarlığıyla da anti-i̇slamist fikirler siyasi söylem bazında bir zemine oturtulmuştur. Bu durum İslamofobik tutumlarda faşizan tutumların da etkin rol oynadığını göstermektedir. Nitekim paylaşılan tweetlerde PKK başta olmak üzere, çeşitli terör örgütleri tarafından İslamofobik söylemler siyaset ve milliyetçilik fikirleriyle kurgulanarak paylaşılmıştır. @CenabiAllah hesabı ve takip ediciler, paylaştıkları siyasi içerikli tweetlerde kendilerini Cumhur i̇ttifakı karşısında konumlandırarak HDP ve Selahattin Demirtaş taraftarlığıyla politik içerikler paylaşmıştır. Öte yandan ilgili hesap ve takipçiler; göçmenler, Diyanet İşleri Başkanlığı, laiklik ve Twitter'da gündem olan farklı konular (asgari ücret, faiz, yılbaşı vb.) özelinde de İslamofobik paylaşımlarda bulunmuştur. Araştırma sonucunda elde edilen bu çıktılar, İslamofobi ile ilgili yapılan daha önceki çalışmaların bulgularıyla da benzerlik taşımaktadır (Imhoff ve Recker, 2012; Fritzsche ve Nelson, 2020).

İslamofobik içerikli paylaşımlar yapan kesimin profil bilgilerine bakıldığında, bu kişilerin aynı zamanda cumhuriyet değerlerini benimseyen kişiler olduğu görülmüştür. Fakat burada önemli bir tezatlık ortaya çıkmaktadır. Bu kişiler hem kendileri dışındaki diğer insanların inanç hürriyetlerine saygı duymamakta hem de bu kesimlere yönelik hakaret etme haklılığını kendinde görmektedir. Bu durum cumhuriyet ülküsünün içerdiği değerlerle kişilerin anladıkları cumhuriyet fikri arasındaki tezatlığı ortaya çıkarmaktadır. Bu güruh içinde aynı zamanda Twitter hesaplarında herhangi bir dini inanca sahip olmadığını ve kendini sözde hümanist ve doğa dostu olduğunu ifade eden kesimler de olmuştur. Ortaya çıkan bu sonuçlarla bireylerin benimsediği dünya görüşleri ile yaptıkları arasında ciddi bir ikilem yaşadıkları rahatlıkla ifade edilebilir. Tüm bu kesimler dışında @CenabiAllah hesabını takip edenler içinde aynı zamanda LGBT taraftarlarının da olduğu tespit edilmiştir. Demokratik bir zeminde fikirlerini rahatça ifade edemediklerini belirten bu kesim, yaptıkları paylaşımlarla Müslümanların değer yargılarını kendi demokratik zemini için kurban etmiştir. Sözde demokratik anlamda faaliyetlerini sergileyen bu tarz yapılanmalar, aslında kendileri için 'öteki' olarak atfettiği inançlara ve toplumun hassasiyetlerine bağnazca ve kutuplaştırıcı bir dille yaklaşmıştır. Bireylerin benimsediği ideolojiler ve kendilerini niteledikleri sıfatlar dışında, Twitter'da İslamofobik içerikler paylaşmada; C neslinin teknolojiye olan düşkünlüğü, tıklanma, takip edilme, gündemde olma ve beğenilme gibi narsist düşüncelerin de önemli birer belirleyici unsur olduğu söylenebilir.

Genel anlamda bu tür sosyal medya hesapları için yapılan tek hukuki yaptırım, ilgili hesabın kapatılması olmaktadır. Her ne kadar ilgili hesaplara kapatma yoluyla erişim engeli getirilse de farklı adlarla yeni hesaplar kurulabilmektedir. Nitekim @CenabiAllah hesabı Ekim 2021'de kapatılmış fakat aynı kişi/ler tarafından yine aynı adla (Allah (c.c) @cenabiallah2) yeni bir Twitter hesabı açılmıştır. Tüm bu sonuçlar ışığında burada öne çıkan soru; bu işin çözüm merkezinin kimler tarafından ve nasıl yapılacağıdır. Çalışmada elde edilen sonuçlar ışığında, İslam dini ve mensuplarına yönelik yapılan bu tür tahkirlere ilişkin; Türkiye Cumhuriyeti Devleti'nin muhatabı Devletler ve uluslararası kurum/kuruluşlarla paydaşlık ve eşgüdüm içerisinde hareket etmesini ve manevi değerlerin korunması noktasında uluslararası düzeyde yapılacak somut çalışmalarda öncü rol oynamasını gündeme getirmektedir. Öte yandan, Diyanet İşleri Başkanlığı da bu tarz durumlarda daha aktif bir biçimde rol oynamalıdır. Kurumun burada benimsemesi gereken dil ve söyleminse i̇slam'ın değer yargılarına uygun düşecek (kavl-i leyyin) şekilde yapması olacaktır. Araştırmada, Twitter özelinde gerçekleşen İslamofobik paylaşımlara odaklanılmıştır. Twitter dışındaki diğer sosyal medya platformlarında da yerli İslamofobik görünümlerin başka noktalarını keşfetmek adına güncel veriler ışığında yeni çalışmaların yapılması önerilmektedir.

\section{Son Notlar}

1 ilk yüzde @CenabiAllah hesabı ikinci yüzde bu hesabı takip eden kişilerin paylaşımlarına karşılık gelen yüzdeyi ifade etmektedir 


\section{Kaynakça}

Abbas, T. (2011). Islamophobia in the United Kingdom: Historical and contemporary political and media discourses in the framing of a 21st-century anti-Muslim racism, Islamophobia. J. Esposito, and i. Kalin içinde, The Challenge of Pluralism in the 21st Century (s. 67-76). Oxford: Oxford University Press.

Abbas, T. (2019). Islamophobia and radicalisation: A vicious cycle. New York: Oxford University Press.

Aguilera-Carnerero, C., and Azeez, A. H. (2016). Islamonausea, not Islamophobia': The many faces of cyberhate speech. Journal of Arab \& Muslim Media Research, 9(1), 21-40. doi:10.1386/jammr.9.1.21_1

Akıner, N. ve Mencet, M. S. (2016). Türkiye'de islamofobi: Mizah dergilerinde İslam'ın temsili. Akademik Incelemeler Dergisi, 11(2), 169-196. doi:10.17550/aid.62268

Allen, C. (2007). Islamophobia and its consequences. S. Amghar, A. Boubekeur, and M. Emerson içinde, European Islam-Challenges for Public Policy and Society (s. 144-167). Brussels: Centre for European Policy Studies.

Allen, C. (2010a). Islamophobia. Surrey: Ashgate Publishing.

Allen, C. (2010b). West Midlands case study. J. G. Mazer, and R. Lambert içinde, Islamophobia and anti-Muslim hate crime: UK case studies (s. 147-181). Exeter: University of Exeter.

Allen, C. (2010c). Fear and loathing: The political discourse in relation to Muslims and Islam in the British contemporary setting. Politics and Religion Journal, 4(2), 221-236.

Andre, V. (2016). Thai cyber-actors: Evidence of an Islamophobic effect. D. Pratt, and R. Woodlock içinde, Fear of Muslims?: International Perspectives on Islamophobia (s. 111-130). Switzerland: Springer.

Aslan, A. (2019). The politics of Islamophobia in Turkey. E. Bayrakl, and F. Hafez içinde, Islamophobia in Muslim Majority Societies (s. 71-92). London: Routledge.

Awan, I. (2014). Islamophobia and Twitter: A typology of online hate against Muslims on social media. Policy \& Internet, 6(2), 133-150. doi:10.1002/1944-2866.poi364

Awan, I. (2016). Islamophobia on social media: A qualitative analysis of the Facebook's walls of hate. International Journal of Cyber Criminology, 10(1), 1-20. doi:10.5281/zenodo.58517

Balcı, Ş. ve Karadeniz, B. (2021). Nefret söylemi pratiği olarak İslamofobi: Fransa'da yükselen İslamofobik söylemlerin Türk yazılı basınında yansıtııma biçimleri. Medya ve Din Araştırmaları Dergisi (MEDiAD), 4(1), 5-31. doi:10.47951/mediad.907354

Bayraklı, E. ve Hafez, F. (2020). European Islamophobia Report. İstanbul: SETA. Erişim adresi: https://www. islamophobiaeurope.com/wp-content/uploads/2020/06/EIR_2019.pdf

Bayraklı, E. ve Yerlikaya, T. (2017). Müslüman toplumlarda islamofobi: Türkiye örneği. Ombudsman Akademik, 2(7). doi:10.32002/ombudsmanakademik.440210

Beka, R. (2019). Islamophobia in the contemporary Albanian public discourse. E. Bayrakl, and F. Hafez içinde, Islamophobia in Muslim Majority Societies (s. 45-58). London: Routledge.

Bleich, E. (2012). Defining and researching Islamophobia. Review of Middle East Studies, 46(2), 180-189. doi:10.1017/S2151348100003402

Burnap, P., and Williams, M. L. (2015). Cyber hate speech on Twitter: An application of machine classification and statistical modeling for policy and decision making. Policy \& Internet, 7(2), 223-242. doi:10.1002/ poi3.85

Büyüköztürk, Ş., Kılıç Çakmak, E., Akgün, Ö. E., Karadeniz, Ş. ve Demirel, F. (2018). Bilimsel araştırma yöntemleri. Ankara: Pegem Akademi.

Büyüktopçu, M. B. ve Gündoğdu, S. (2019). Alman karikatürleri örneğinde İslamofobi. Kafkas Üniversitesi Sosyal Bilimler Enstitüsü Dergisi, Fuat Sezgin Özel Sayısı, 91-102. doi:10.9775/kausbed.2019.020

Chau, M., and $\mathrm{Xu}$, J. (2007). Mining communities and their relationships in blogs: A study of online hate groups. International Journal of Human-computer Studies, 65(1), 57-70. doi:10.1016/j.ijhcs.2006.08.009 
Cherribi, S. (2011). An obsession renewed: Islamophobia in the Netherlands, Austria, and Germany. J. L. Esposito, and i. Kalın içinde, Islamophobia: The Challenge of Pluralism in the 21st Century (s. 47-62). Oxford: Oxford University Press.

Cimino, R. (2005). "No God in common:" American Evangelical discourse on Islam after 9/11. Review of Religious Research, 47(2), 162-174. doi:10.2307/3512048

Deeb, L. (2010). Gendering Islamophobia and Islamophilia: The case of Shi'i Muslim women in Lebanon. A. Shryock içinde, Islamophobia / Islamophilia Beyond the Politics of Enemy and Friend (s. 94-110). Bloomington: Indiana University Press.

Dirlik, A. (1996). Chinese history and the question of orientalism. History and Theory, 35(4), 96-118.

Douglas, K. M., McGarty, C., Bliuc, A. M., and Lal, G. (2005). Understanding cyberhate: Social competition and social creativity in online white supremacist groups. social science Computer Review, 23(1), 68-76. doi:10.1177/0894439304271538

Forman, J., Creswell, J. W., Damschroder, L., Kowalski, C. P., and Krein, S. L. (2008). Qualitative research methods: Key features and insights gained from use in infection prevention research. American Journal of Infection Control, 36(10), 764-771. doi:10.1016/j.ajic.2008.03.010Get

Fritzsche, L., and Nelson, L. (2020). Refugee resettlement, place, and the politics of Islamophobia. Social \& Cultural Geography, 508-526. doi:10.1080/14649365.2019.1672775

Gorman, C. S., and Culcasi, K.(2021). Invasionand colonization: Islamophobia and anti-refugee sentiment in West Virginia. Environment and Planning C: Politics and Space, 39(1), 168-183. doi:10.1177/2399654420943897

Gökmen, H. (2018). Hollandalı politikacı Geert Wilders'ın "Fitna" filmi çerçevesinde bir algı ve imaj olarak islamofobi. Antakiyat, 1(1), 84-98.

Graham, M., Milanowski, A., and Miller, J. (2012). Measuring and promoting inter-rater agreement of teacher and principal performance ratings. The Center for Educator Compensation and Reform (CECR), 1-33. Erişim adresi: https://eric.ed.gov/?id=ED532068

Himmat, H. (2004). Islamophobia and its consequences on young women. I. Ramberg, Seminar report for the council of Europe: European Youth Centre içinde (s. 85-90). Budapest: Directorate of Youth and Sport of the Council of Europe.

Imhoff, R., and Recker, J. (2012). Differentiating Islamophobia: Introducing a new scale to measure Islamoprejudice and secular Islam critique. Political Psychology, 33(6), 811-824. doi:10.1111/j.1467-9221.2012.00911.x

Jaishankar, K. (2008). Cyberhate: Antisocial networking in the Internet. International Journal of Cyber Criminology, 2(2), 16-20.

Jung, J. H. (2012). Islamophobia? Religion, contact with Muslims, and the respect for Islam. Review of Religious Research, 54(1), 113-126. doi:10.1007/s13644-011-0033-2

Kanbur, Y.(2020). İslamofobik “kimlikçilik hareketi”nin Twitter görünümü. MEDIAD, 3(2), 265-284. doi:10.47951/ mediad.837405

Kassarjian, H. H. (1977). Content analysis in consumer research. Skip Nav Destination, 4(1), 8-18. doi:10.1086/208674

Kaya, C. ve Akıncı, A. (2018). Türkiye'de İslamofobinin yansımaları. Küresel İktisat ve İ̧̧letme Çalışmaları Dergisi, 7(13), 82-89. Erişim adresi: http://dergipark.gov.tr/gumusgjebs

Kirk, J., and Miller, M. L. (1986). Reliability and validity in qualitative research (Qualitative research methods series). London: Sage.

Kumar, D. (2007). Islam and Islamophobia. International Socialist Review, 52, 26-32.

Kurtuluş, Y. (2009). 11 Eylül 2001 sonrası İslam’la ilgili medya değerlendirmeleri. Marmara Üniversitesi Sosyal Bilimler Enstitüsü Doktora Tezi.

López, F. B. (2011). Towards a definition of Islamophobia: Approximations of the early twentieth century. Ethnic and Racial Studies, 34(4), 556-573. doi:10.1080/01419870.2010.528440 
Magdy, W., Darwish, K., \& Abokhodair, N. (2015). Quantifying public response towards Islam on Twitter after Paris attacks. ArXiv, abs/1512.04570

Massoumi, N., Mills, T., and Miller, D. (2017). Islamophobia, social movements and the state: For a movement-centred approach. N. Massoumi, T. Mills, and D. Miller içinde, What is Islamophobia?: Racism, Social Movements and the State (s. 3-34). London: Pluto Press.

Mayring, P. (2000). Qualitative content analysis. Forum Qualitative Sozialforschung/Qualitative Social Research, 1(2), 1-10. doi:10.17169/fqs-1.2.1089

Meer, N. (2013). Racialization and religion: Race, culture, and difference in the study of antisemitism and Islamophobia. Ethnic and Racial Studies, 36(3), 385-398. doi:10.1080/01419870.2013.734392

Neuendorf, K. (2002). The content analysis guidebook. California: Sage.

Osman, M. N. (2019). The confluence of race and religion in understanding Islamophobia in Malaysia. E. Bayraklı, and F. Hafez içinde, Islamophobia in Muslim Majority Societies (s. 161-174). London: Routledge.

Özçelik, T. G. (2021). Self-orientalism and the mediass role in Turkey before 2000. OPUS, 11(35), 2179-2208. doi:10.26466/opus.856102

Perry, B., and Olsson, P. (2009). Cyberhate: The globalization of hate. Information \& Communications Technology Law, 18(2), 185-199. doi:10.1080/13600830902814984

Puschmann, C., Ausserhofer, J., Maan, N., and Hametner, M. (2016). Information laundering and counter-publics: The news sources of Islamophobic groups on Twitter. (s. 143-150). The Workshops of the Tenth International AAAI Conference on Web and Social Media in the Newsroom: Technical Report WS-16-19. May 17-20, 2016, Cologne, Germany.

Saeed, T. (2016). Islamophobia and securitization: Religion, ethnicity, and the female voice. Lahore: Palgrave Macmillan.

Said, E. (1978). Orientalism. London: Penguien.

Schreier, M. (2012). Qualitative content analysis in practice. London: Sage publications.

Shah, S. Z. (2019). Post-coloniality, Islamization and secular elites: Tracing Islamophobia in Pakistan. E. Bayraklı, and F. Hafez içinde, Islamophobia in Muslim Majority Societies (s. 59-70). London: Routledge.

Sheridan, L. P. (2006). Islamophobia pre-and post-September 11th, 2001. Journal of Interpersonal Violence, 21(3), 317-336. doi:10.1177/0886260505282885

Shirin, H. (2012). What's the point? Anti-racism and students' voices against Islamophobia. Race Ethnicity and Education, 15(1), 101-120. doi:10.1080/13613324.2012.638867

Temel, M. (2019). Türkiye'de siyaset yönelimli İslamofobik retorik: Refahyol hükümeti dönemi basını örneği. Erciyes Üniversitesi Sosyal Bilimler Enstitüsü, Doktora Tezi.

Temel, M. (2020). Türkiye'de basın-iktidar ilişkileri çerçevesinde islamofobik söylem. Medya ve Din Araştırmaları Dergisi (MEDIAD), 3(1), 29-59.

Terri, A. W. (2019). Islamophobia: Social distance, avoidance, and threat. Sociological Spectrum, 39(6), 359374. doi:10.1080/02732173.2019.1704668

Tsuria, R. (2013). The video Three Things About Islam: Islamophobia online or a religious dialogue? Scripta Instituti Donneriani Aboensis, 25, 222-231. doi:10.30674/scripta.67442

Türkoğlu, H. S., and Türkoğlu, S. (2021). Orientalism, Islamophobia, and the concept of otherization through civil conflict, digital platform Netflix: The example of the Messiah series. I. Tombul, and G. Sarı içinde, Handbook of Research on Contemporary Approaches to Orientalism in Media and Beyond (s. 730-759). IGI Global. doi:10.4018/978-1-7998-7180-4.ch042

UenaL, F., Bergh, R., Sidanius, J., Zick, A., KimeL, S., and Kunst, J. R. (2021). The nature of Islamophobia: A test of a tripartite view in five countries. Personality and Social Psychology Bulletin, 47(2), $275-292$. doi:10.1177/0146167220922643 
Vidgen, B., and Yasseri, T. (2020). Detecting weak and strong Islamophobic hate speech on social media. Journal of Information Technology \& Politics, 17(1), 66-78. doi:10.1080/19331681.2019.1702607

vikipedi. (t.y.). İslam. Erişim adresi: https://tr.wikipedia.org/wiki/\%C4\%Boslam

Yel, A. (2021). Islamophobia as cultural racism. Insight Turkey, 23(2), s. 169-190. Erişim adresi: https://www. jstor.org/stable/10.2307/27028545

Yel, A. M. ve Nas, A. (2014). Insight Islamophobia: Governing the public visibility of Islamic lifestyle in Turkey. European Journal of Cultural Studies, 17(5), 567-584. doi:10.1177/1367549413515258

Yıldırım, A. ve Şimşek, H. (2011). Sosyal bilimlerde nitel araştırma yöntemleri. Ankara: Seçkin.

Yin, R. K. (2018). Case study research and applications. Los Angeles: Sage.

Yusha'u, M. J. (2015). Extremism or terrorism: Communicating Islamophobia on YouTube in the Norwegian attacks. Journal of Arab \& Muslim Media Research, 8(2), 171-191. doi:10.1386/jammr.8.2.171_1

Zaal, M. (2012). Islamophobia in classrooms, media, and politics. Journal of Adolescent \& Adult Literacy, 55(6), 555-558. doi:10.1002/JAAL.00066

Zahed, S. E. (2019). Internalized Islamophobia: The making of Islam in the Egyptian media. E. Bayraklı, and F. Hafez içinde, Islamophobia in Muslim Majority Societies (s. 137-160). London: Routledge. 


\title{
MEDIAD
}

\section{Islamophobic Posts on Social Media: The Twitter Case}

\author{
Mehmet Sinan TAM
}

\section{Extended Abstract}

In the most general sense, Islamophobia refers to negative attitudes or feelings towards Islam or Muslims (Bleich, 2012, p. 185). It is not possible to predict exactly when Islamophobia turned into a mass state, but it is striking that the date when this situation was conceptualized coincides with the 2oth century and the turning point here is September 11, 2001. The hatred and fear of the Islamic identity, especially after the attack on the World Trade Center in the 21st century, has led to an increase in anti-Islam discourses relative to previous years (Sheridan, 2006, p. 317). Although Islamophobic tendencies have emerged outside the Islamic world, this trend is also encountered in countries with a large majority of Muslims. This situation has been demonstrated academically in studies conducted in Turkey, Pakistan, Egypt, Albania, and Malaysia. When evaluated on a country basis, Islamophobia is frequently seen in the law, university, business, and media sectors in Turkey in recent years, while it is heavily processed in traditional media with advertisements and television images, films, and soap operas (Yel and Nas, 2014). The first pillar of Islamophobic tendencies in Turkey is produced in the press or on the political ground. Then, the subject is moved to the media or political arena according to the place where it was first produced and operated mutually (Temel, 2019, p. 164). Then, the subject is moved to the media or political arena according to the place where it was first produced and operated mutually (Temel, 2019, p. 164). In daily life, the people who are exposed to Islamophobic discourses are mostly women, and some women are intensely exposed to actual attacks or psychological pressures, apart from discourses (terrorist, I will cut off your head, etc.) (Himmat, 2004).

\section{Method}

In the study, although it is expressed with different names by the three monotheistic religions, Islamophobic posts on Twitter regarding the creator, which is a common value, and the material and spiritual values of Muslims are examined. The study aims to reveal the Islamophobic views, shares, and legitimation efforts on the micro-level of social media in the macro sense, through the @CenabiAllah account, which makes islamophobic posts on Twitter. Since qualitative research is more suitable for purposive sampling, the sample of the study was determined based on the criterion type of purposive sampling (Forman et al., 2008, p. 767; Büyüköztürk et al., 2018, pp. 94-95). The number of followers was taken as a basis in the selection of the Twitter account examined in this research. The Twitter account opened under the name of Allah, which is included in the sample of the research in question, uses the origin of the @CenabiAllah and is the most followed account with 222.2 thousand followers in Turkish. In the research, the tweets of the relevant account between 25.10.2020 and 03.01.2021 were examined according to the case study design among the qualitative research designs (Yin, 2018).

\section{Results}

The @CenabiAllah account was opened in 2013, and the first tweet reached was dated 31.05.2013, "The Resistance in Taksim is Growing. Tens of thousands are marching against Fascism. \#direngeziparki" was shared with the tag. It has been observed that the account in question deleted some of its past tweets, and it focused on Islamophobic posts, especially after 2018. In the tweets of the @CenabiAllah account, which is still actively shared on Twitter, and those who follow this account, common posts were made on the themes of Islamophobia, self-qualification, language, politics, other heavenly religions, propaganda, addressing, interaction, and humiliating women. The account under the username of Allah made a difference in the theme of news sources and followers on the theme of racism. The Twitter account Allah and its followers shared Islamophobic tweets about religious values and discourses, the Qur'an, Muslims, angels, contempt of Allah, belief in the hereafter, prophets, mocking the concept of sin, the qualities of Allah, fard, Arabic, and religious institutions and individuals. It has been found that not only the religion of Islam but also the values of Christianity and Judaism have been undermined. Twitter users reacted to the Islamophobic posts under four headings. These responses were respectively prudent calls (56\%), swearing/insulting (22\%), warning with verses in the Qur'an (19.5\%), and asking questions (2.4\%). Attributes of Allah, prophets, Muslims, angels, contempt 
of Allah, and the concept of sin have been extensively associated with ridicule. Atheism and belief in the hereafter have also been other Islamophobic titles with an intense relationship.

\section{Discussion}

As a result of the research, the account, which was opened in 2013 under the image of an ordinary Twitter account, has over time become a common meeting and a discourse point of different segments that carry Islamophobic thoughts. Islamophobic tweets in Turkey are produced and shared under the headings of politics, immigrants, religion, and secularism. In addition, narcissistic thoughts such as the C generation's fondness for technology, being clicked, followed, being on the agenda, and being liked can also cause Islamophobic thoughts to be produced. The study raises the need for Turkey to play a leading role in the protection of moral values to be made with international organizations regarding such insults made specifically against Islam and to prepare legal regulations for the protection of material and moral values with social media representatives in Turkey.

\section{Araștırmacıların Katkı Oranı Beyanı/ Contribution of Authors}

Araştırma tek bir yazar tarafından yürütülmüştür.

The research was conducted by a single author.

$* * * * * * * *$

\section{Çıkar Çatışması Beyanı / Conflict of Interest}

Çalışma kapsamında herhangi bir kurum veya kişi ile çıkar çatışması bulunmamaktadır.

There is no conflict of interest with any institution or person within the scope of the study.

Intihal Politikası Beyanı / Plagiarism Policy

Bu makale iThenticate yazılımıyla taranmıştır. İntihal tespit edilmemiştir.

This article has been scanned by iThenticate. No plagiarism was detected.

$* * * * * * * *$

\section{Bilimsel Araştırma ve Yayın Etiği Beyanı / Scientific Research and Publication Ethics Statement}

Bu çalışmada “Yükseköğretim Kurumları Bilimsel Araştırma ve Yayın Etiği Yönergesi” kapsamında uyulması belirtilen kurallara uyulmuştur.

In this study, the rules stated in the "Higher Education Institutions Scientific Research and Publication Ethics Directive" were followed 